\title{
Geochemical assessment of fluoride enrichment and nitrate contamination in groundwater in hard-rock aquifer by using graphical and statistical methods
}

\author{
Sunil Kumar Srivastava ${ }^{1, *}$ and A L Ramanathan ${ }^{2}$ \\ ${ }^{1}$ Department of Chemical Engineering/Chemistry, Jaypee University of Engineering and Technology, \\ Guna 473226 , India. \\ ${ }^{2}$ School of Environmental Science, Jawaharlal Nehru University, New Delhi 110 067, India. \\ *Corresponding author. e-mail: sunil16sster@gmail.com
}

MS received 1 September 2017; revised 30 January 2018; accepted 4 February 2018; published online 10 September 2018

This systematic study was carried out with objective to delineate the various sources responsible for $\mathrm{NO}_{3}^{-}$contamination and $\mathrm{F}^{-}$enrichment by utilizing statistical and graphical methods. Since Central Ground Water Board, India, indicated susceptibility of $\mathrm{NO}_{3}^{-}$contamination and $\mathrm{F}^{-}$enrichment, in most of the groundwater, $\mathrm{NO}_{3}^{-}$and $\mathrm{F}^{-}$concentration primarily observed $>45$ and $>1.5 \mathrm{mg} / \mathrm{L}$, respectively, i.e., higher than the permissible limit for drinking water. Water Quality Index (WQI) indicates $\sim 22.81 \%$ groundwater are good-water, $\sim 71.14 \%$ groundwater poor-water, $\sim 5.37 \%$ very poor-water and $0.67 \%$ unsuitable for drinking purpose. Piper diagram indicates $\sim 59.73 \%$ groundwater hydrogeochemical facies are $\mathrm{Ca}-\mathrm{Mg}-\mathrm{HCO}_{3}$ water-types, $\sim 28.19 \% \mathrm{Ca}-\mathrm{Mg}-\mathrm{SO}_{4}-\mathrm{Cl}$ water-types, $\sim 8.72 \% \mathrm{Na}-\mathrm{K}-\mathrm{SO}_{4}-\mathrm{Cl}$ watertypes and $3.36 \% \mathrm{Na}-\mathrm{K}-\mathrm{HCO}_{3}$ water-types. This classification indicates dissolution and mixing are mainly controlling groundwater chemistry. Salinity diagram indicate $\sim 44.30 \%$ groundwater under in low sodium and medium salinity hazard, $\sim 49.66 \%$ groundwater fall under low sodium and high salinity hazard, $\sim 3.36 \%$ groundwater fall under very-high salinity hazard. Sodium adsorption ratio indicates $\sim 97 \%$ groundwater are in excellent condition for irrigation. The spatial distribution of $\mathrm{NO}_{3}^{-}$indicates significant contribution of fertilizer from agriculture lands. Fluoride enrichment occurs in groundwater through the dissolution of fluoride-rich minerals. By reducing the consumption of fertilizer and stress over groundwater, the water quality can be improved.

Keywords. Hydrogeochemistry; fluoride; nitrate; Guna; hard-rock.

\section{Introduction}

The nitrate contamination and enrichment of fluoride in groundwater is a very common problem observed worldwide by various researchers (Bohlke 2002; Kundu et al. 2008; Jalali 2009; KyoungHo et al. 2009; Suthar et al. 2009; Akao et al. 2014; Subba Rao et al. 2016; Sajil Kumar 2017). Nitrate contamination in groundwater occurs due to leaching of nitrate from agriculture lands, sewage effluent or fertilizer sink (Bohlke 2002; Kundu et al. 2008; Jalali 2009; Kyoung-Ho et al. 2009; Suthar et al. 2009; Ngounou Ngatch and Djoret 2010; Akao et al. 2014). India is also suffering from nitrate contamination and fluoride enrichment problems (Handa 1975; Sajil Kumar et al. 2014; Subba Rao et al. 2016). According to UNICEF (1999), India possesses $\sim 14.1 \%$ of total fluoride deposits 
present in the earth's crust and its 17 states are endemic in fluorosis. Fluoride is necessary for teeth up to $1.50 \mathrm{mg} / \mathrm{L}$ (BIS 2012). High concentration of fluoride in groundwater has been reported in central-western India and this enrichment occurs through geogenic sources (Handa 1975).

The hydrogeochemical behaviour of nitrate in groundwater is strongly influenced by the presence of plants (organic load in soil), animal waste and anthropogenic input (fertilizer, industrial effluent, and animal excreta) (Spalding and Exner 1993; Jalali 2009; Sajil Kumar 2017). In general nitrate in groundwater originate from nitrogen sources on the land surface in the soil zone or subsoil zone, where nitrogen-rich wastes are buried. The ammonification and nitrification are the processes that normally occur above the water table in the soil zone, where organic matter and oxygen are ample and help in the formation of nitrate on the top layer of aquifers. The shallow groundwater aquifer of Guna district is possessing highly permeable sediment or fractured rocks that commonly contains high dissolved oxygen (DO) and in these hydrogeological environments nitrate commonly migrates large distances from input areas. Nitrate is a very common constituent in the groundwater, especially in shallow aquifer (Jalali 2009; Akao et al. 2014; Sajil Kumar 2017). The maximum admissible concentration (MAC) of nitrate in most of the countries ranges from 45$50 \mathrm{mg} / \mathrm{L}\left(\sim 10-11 \mathrm{mg} / \mathrm{L} \mathrm{NO}_{3}-\mathrm{N}\right)$ (WHO 2011; Akao et al. 2014). Since the geochemical processes [ion-exchange, oxidation-reduction (redox reaction) and adsorption] occurring within the groundwater aquifers and the reaction with aquifer minerals have a profound effect on groundwater chemistry, further contribution of anthropogenic source (industries effluent, fertilizer industry and fertilizer used in agriculture field) significantly influences groundwater quality (Cederstrom 1946; Moore et al. 2006).

The groundwater is the major source of water for drinking, agriculture and industrial requirement in this subtropical climatic zone of India. The annual report published by Central Groundwater Board indicates susceptibility of contamination of groundwater aquifer by nitrate (CGWB 2013). There are few major industries [fertilizer industry (National Fertilizer Ltd., India), sugar industry and Gas Authority of India Ltd. (GAIL India)] and numbers of small-scale industries located in Guna district. These industries are also dependent on water resources in various proportions along with major utilization of water for irrigation and domestic needs. These hard-rock aquifers suffering by the scarcity of water; further unplanned extraction of groundwater causes stress on water quality and quantity (CGWB 2013). Extraction of water was carried through semiconfined hard-rock aquifer causing a stress over the aquifers, which support faster dissolution of minerals through rock (Srivastava and Ramanathan 2012). The mixing of groundwater by dispersion is also important for transport of contaminant in groundwater aquifer (Drever 1988). Farming in the study area, performing intensive agriculture activities creates stress over groundwater quantity (forces depletion of water table) and further excess utilization of fertilizers influence its quality. Since most of the bore wells are located in agriculture land or nearby agriculture land, it increases the susceptibility of groundwater contamination by leaching of fertilizer. Most of the study area is under major crops; indicate the high load of water on groundwater, since groundwater is the major source of water for irrigation in agriculture field and drinking requirements (CGWB 2013). The groundwater quality of this study area is susceptible to contamination through geogenic (through geology) and anthropogenic (through industrial effluent and other major minerals mining) activities.

India is suffering from high fluoride (through geogenic source) and nitrate (through agriculture field and fertilizer industry) in groundwater in many cities and localities (Handa 1975; UNICEF 1999; Assaf and Saadeh 2009; Agarwal 2012; Reddy 2013; Sajil Kumar et al. 2014). The nitrate contamination through leaching from agriculture land is the major concern in India because more than $70 \%$ population of India depends on agricultural activities. The urea $\left(\mathrm{NH}_{2} \mathrm{CONH}_{2}\right)$ is intensively used as chemical fertilizer in all these agriculture lands, further leaching along with irrigated water and rainwater causes contamination of groundwater (Ako et al. 2014). Hence, this systemic study was carried out to understand the hydrogeochemistry of groundwater as well as the influence of geogenic and anthropogenic sources on groundwater quality. The susceptibility of fluoride and nitrate has motivated to look for detailed study of hydrogeochemistry of this hard-rock aquifer (CGWB 2013). The geochemical assessment of groundwater quality in the hard-rock aquifer of the Guna district was carried out with an objective to delineate the various sources for the enrichment of fluoride and contamination for nitrate in groundwater. 


\section{Study area}

The Guna is located in northwestern part of Madhya Pradesh, India. Geographically, it lies between latitude $23^{\circ} 53^{\prime}-25^{\circ} 06^{\prime} \mathrm{N}$ and longitude $76^{\circ} 48^{\prime}-78^{\circ} 16^{\prime} \mathrm{E}$ and map drawn with the help of Survey of India (SOI) Topo Sheet No. 54 G, H, and L (figure 1). The Guna district (the total area $\sim 6484.63 \mathrm{~km}^{2}$ ) area is divided into $\sim 15.56 \%$ forest area and $\sim 50.67 \%$ sown area, while $\sim 62.24 \%$ as a cultivable area of total area (CGWB 2013). It is divided into 6 blocks (Kumbhraj, Chachoda, Raghogarh, Aron, Guna, and Bamori), which have 1260 villages with total population 12,41,519 (Census of Govt. of India 2011). The study area belongs to the subtropical climatic zone of India, with a temperature $7.4^{\circ} \mathrm{C}$ in winter (November-January) to $45^{\circ} \mathrm{C}$ in summer (April-June) (Indian Meteorological Department 2016). The study reported average rainfall $1042.7 \mathrm{~mm}$. Approximately 92.2\% of the total annual rainfall occurs during the monsoon season (June-September). Hence, major recharge of groundwater occurs in monsoon period. The Chachoda block of Guna district receives maximum, i.e., $1140.20 \mathrm{~mm}$ (India Meteorological Department 2016).

The geology of the study area indicates predominantly Vindhyan sandstones, shales, and limestone (figure 1). In the study area, the waterbearing formation is available in weathered fractured jointed Deccan trap shale and in Vindhyan sandstones (CGWB 2013). The geological formations indicate $\sim 70 \%$ of district area is geologically covered by Deccan trap basalt of Malwa Group (Cretaceous to Paleozoic Age) representing a vast period of geological formation (figure 1). The Deccan trap generally formed by the number of basaltic lava flows, whose water holding capacities varies in each segment of the lava flow. The phreatic aquifer occurs in weathered, jointed and fractured basalts. A few areas in Guna district, where the basaltic layer is extensive caused a formation of continuous aquifer but due to the low permeability of the weathered basalt, these aquifers sustains only limited groundwater withdrawal. The groundwater at deeper levels occurs under semi-confined to confined conditions in vesicular, jointed and fractured basalts (CGWB 2013). In general, the yield of these wells in this formation varies from 3.5-8 l/sec (CGWB 2013). The unit draft of the wells in study area varies from 0.001-0.008 $\mathrm{mcm} /$ year for dug-wells and $0.005-0.017 \mathrm{mcm} /$ year for tube-wells (CGWB 2013).
The northern parts are laterite of Cenozoic age occurs as boulders capping, the Vindhyan and Deccan trap formations (CGWB 2013). It is ferruginous in nature with a small thickness $(1-5 \mathrm{~m})$, while alluvium (Quaternary age) available in the narrow belt along with floodplain of the River Kumo, Parvati, and Sindh (CGWB 2013). These comprise of the pebble beds, gravels, silts, and sands. The granular portion of this formation causes good aquifer with shallow thickness (CGWB 2013). The depths to water level are ranges between 3.80 and $18.94 \mathrm{~m}$ below the ground level (premonsoon) and 1.54-6.50 m (post-monsoon). A very small area of Guna district occupied by Lamata Group and Vindhyan Formation. The Lameta Group (Cretaceous age) comprising siliceous limestone and highly fossiliferous sandstone is exposed at the 8-25 km southwest of the Sirsi in the northern part of the Guna district. It is horizontally disposed underneath the Deccan trap formation. The groundwater in this group occurs under a phreatic condition with good yield. In Vindhyan formation sandstones are intercalated with shale beds and exposed in the northern and northwestern parts of the district (Bamori and Guna blocks). The hard-rock is fractured and jointed at the different depth, forming it a potential aquifer at deeper levels (CGWB 2013). The groundwater occurring in confined and semi-confined aquifers is being exploited through bore wells by using motor pumps. In general condition, the yield of these bore wells is fairly good $(2-10 \mathrm{l} / \mathrm{sec})$. The depth to water level ranges from 3.70 to $22.10 \mathrm{~m}$ and 0.07 to $9.98 \mathrm{~m}$ below ground level during pre- and post-monsoon season, respectively. The soils of the study area are clayey, loamy, fine and black. These soils can broadly be divided into three major groups: clayey soil, well-drained loamy soil and moderately deep to deep fine soil.

The geomorphology of the study area is located in eastern-western of the Vindhyan ranges. It has the Sindh valley, the Malwa plateau and most of the area covered by the Parbati river valley, Binaganj and Chachoda hills (CGWB 2013). The low-level plateau, plain of extrusive origin with terrace/rocky bench and floodplains (including in filled river bed) along the course of the river observed physiographical. The other landforms are low structural plateau and plains of Proterozoic rocks. The maximum elevations $(561 \mathrm{~m})$ and minimum elevations $(324 \mathrm{~m}$ ) were observed in the study area. The study area falls in the Yamuna drainage system along with few seasonal rivers. The most of 
GROUNDWATER SAMPLING LOCATIONS IN GUNA DISTRICT

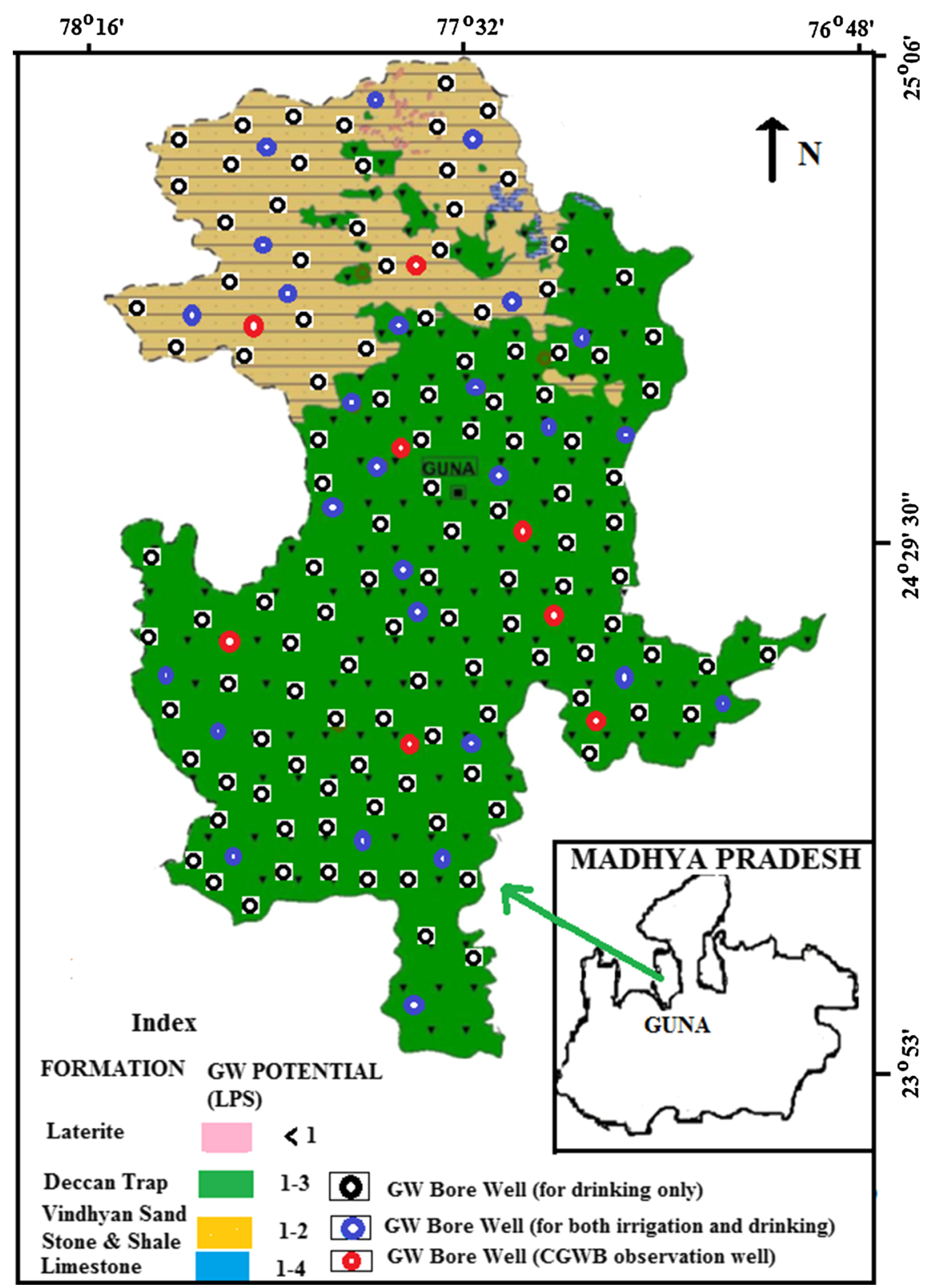

Figure 1. Study area.

area drains by the Parbati and Kuno River, which are tributaries of the Chambal River. The eastern part of the district is drained by the Sindh. It was observed that the flow direction for all these rivers is towards the north with the low gradient.

\section{Methodology}

The systematic sampling of groundwater was carried out in post-monsoon October 2016 to understand the hydrogeochemistry of groundwater. A Garmin Global Positioning System (GPS Model Garmin Etrex 10) was used for identifying the suitable sampling locations in the district. Total 149 groundwater samples were collected in October 2016 through selected bore wells. Out of these wells 114 used exclusively for drinking purpose, 27 for both irrigation and drinking and 8 wells used as an observation well. The physical parameters $[\mathrm{pH}$, temperature, electrical conductivity (EC), dissolved oxygen (DO), oxidation-reduction potential (ORP), total dissolved solids (TDS) and total suspended matter (TSM)] were measured in the field at the time of sampling by using digital electrodes [pH meter (Thermo Orion Star A321), temperature (thermometer) EC (Milwauke MW803), DO (Model No. DO700), ORP (Thermo Orion 
Star A211), TDS (Milwauke MW803)] and these parameters result were cross-checked in Jaypee University research laboratory on the same day. For analysis of cations $100 \mathrm{ml}$ samples were filtered using $0.45 \mu \mathrm{m}$ filter paper and preserved on site with ultra-pure $\mathrm{HNO}_{3}\left(\mathrm{H}_{3} \mathrm{BO}_{3}\right.$ was used as a preservative for nitrate) and stored at $4^{\circ} \mathrm{C}$ to avoid any chemical alteration to groundwater properties during transportation and handling (APHA 1995). Acidification stops most bacterial growth, blocks oxidation reactions and prevents adsorption or precipitation of cations (Appelo and Postma 2005). Sodium and potassium were analyzed by an AIMIL, PE I Flame Photometer following the standard methods as given in APHA (1995). An atomic absorption spectrophotometer (ShimadzuAA-6800) was used for the analysis of trace metals $(\mathrm{Fe}, \mathrm{Cu}, \mathrm{Pb}, \mathrm{Hg})$ and alkaline earth metals $(\mathrm{Mg}$ and $\mathrm{Ca})$. Anions $\left(\mathrm{SO}_{4}^{2-}, \mathrm{NO}_{3}^{-}, \mathrm{PO}_{4}^{3-}\right.$ and silicate) were analyzed by using a UV/V spectrophotometer (JENWAY 6505) as per standard methods described in APHA (1995). Fluoride was analyzed using a fluoride ion selective electrode (WENSER) and cross-verified by SPADNS methods (APHA 1995). Bicarbonate and chloride were analyzed by titration methods using the standard procedure as given in APHA (1995). The accuracy of analysis was calculated by applying charge balance formulae as given below (Appelo and Postma 2005)

$$
\begin{aligned}
& \text { Electrical charge balance } \\
& \qquad=\frac{\left(\sum^{+} \text {Cations }+\sum^{+} \text {Anions }\right)}{\left(\sum^{+} \text {Cations }-\sum^{+} \text {Anions }\right)} \times 100 .
\end{aligned}
$$

Cations and anions are expressed in meq/L and inserted with their charge sign. The spatial distribution of nitrate and fluoride was carried out by using GIS software 'Origin Pro 8'.

\section{Results and discussion}

The summaries of statistical analysis of hydrogeochemical parameters [pH, EC, TDS, DO, $\mathrm{F}^{-}, \mathrm{Cl}^{-}, \mathrm{HCO}_{3}^{-}, \mathrm{SO}_{4}^{2-}, \mathrm{NO}_{3}^{-}, \mathrm{H}_{3} \mathrm{SiO}_{4}^{-}, \mathrm{Na}^{+}, \mathrm{K}^{+}$, $\mathrm{Mg}^{2+}, \mathrm{Ca}^{2+}, \mathrm{Fe}^{2+}, \mathrm{Cu}^{2+}$ and $\left.\mathrm{Pb}^{2+}\right]$ of the various block of the Guna district are given in table 1. The interpretation of statistical data indicates significant role of geology on hydrochemistry of Guna district. The high standard deviations in few hydrogeochemical parameters indicate a possible anthropogenic influence on the quality of groundwater (Ranjan et al. 2017). The geogenic contribution for the same geological area is almost in the similar range but in this analysis few samples show very high value indicates the possibility of anthropogenic input (table 1). Almost all groundwater samples of Guna district show good charge balance within the range of $\pm 5.0 \%$ error. These ranges of error are generally considered acceptable since it is very difficult to analyze all cations and anions (Berner and Berner 1987; Edmond et al. 1995; Huh et al. 1998; Srivastava and Ramanathan 2008). The concentration of major cations and anions in groundwater samples show following trend respectively $\mathrm{Ca}^{2+}>\mathrm{Na}^{+}>\mathrm{Mg}^{2+}>\mathrm{K}^{+}$and $\mathrm{HCO}_{3}^{-}>\mathrm{Cl}^{-}>\mathrm{SO}_{4}^{2-}>$ $\mathrm{NO}_{3}^{-}>\mathrm{F}^{-}=\mathrm{PO}_{4}^{3-}$ with few exceptions may be due to anthropogenic input in groundwater.

\subsection{Water chemistry}

Most of the groundwater samples collected from the study area were colourless, odourless with high DO value; while few showed exceptions in colour changes with time. The groundwater samples collected from Maksudangarh $\left(24^{\circ} 3.696^{\prime} \mathrm{N}\right.$; $\left.77^{\circ} 15.224^{\prime} \mathrm{E}\right)$ and Silvati $\left(24^{\circ} 56.316^{\prime} \mathrm{N} ; 76^{\circ} 57.217^{\prime} \mathrm{E}\right)$ show colour change from colourless to yellow. While groundwater samples collected from Diroli $\left(23^{\circ} 59.290^{\prime} \mathrm{N} ; \quad 77^{\circ} 15.325^{\prime} \mathrm{E}\right)$, Dharnvada $\left(24^{\circ} 35.143^{\prime} \mathrm{N} ; 77^{\circ} 06.114^{\prime} \mathrm{E}\right)$, Senboard $\left(24^{\circ} 44.861^{\prime}\right.$ $\left.\mathrm{N} ; 7^{\circ} 03.648^{\prime} \mathrm{E}\right)$ changes from colourless into red, indicating possibilities of various geochemical reaction occurring in groundwater due to the presence of trace metal ions in water. The colour change in groundwater may be due to oxidation of high concentration of iron, because when this water was pumped out from well it reacts with atmospheric oxygen and precipitates out as $\mathrm{Fe}(\mathrm{OH})_{3}$ (Appelo and Postma 2005).

Almost all groundwater samples show $\mathrm{pH}$ in the range of $6.7-8.78$ with mean value 7.15 and standard deviation 0.29 (table 1). The significant amount of EC observed in few samples may be due to leaching of fertilizer from agriculture land and in few cases other effluent mixing with groundwater (Jalali 2009). It is also justified by good correlation between EC and Nitrate (figure 10). EC ranges for 300-4100 $\mu \mathrm{S} / \mathrm{cm}$ with mean value $997.11 \mu \mathrm{S} / \mathrm{cm}$ for the study area, while each block shows significant EC with variations (table 1). Total dissolved solids (TDS) range from 210 to $2800 \mathrm{mg} / \mathrm{L}$ with mean value $697.98 \mathrm{mg} / \mathrm{L}$ (table 1). The dissolved silica concentration remains constant in almost all blocks with low standard deviation indicating 


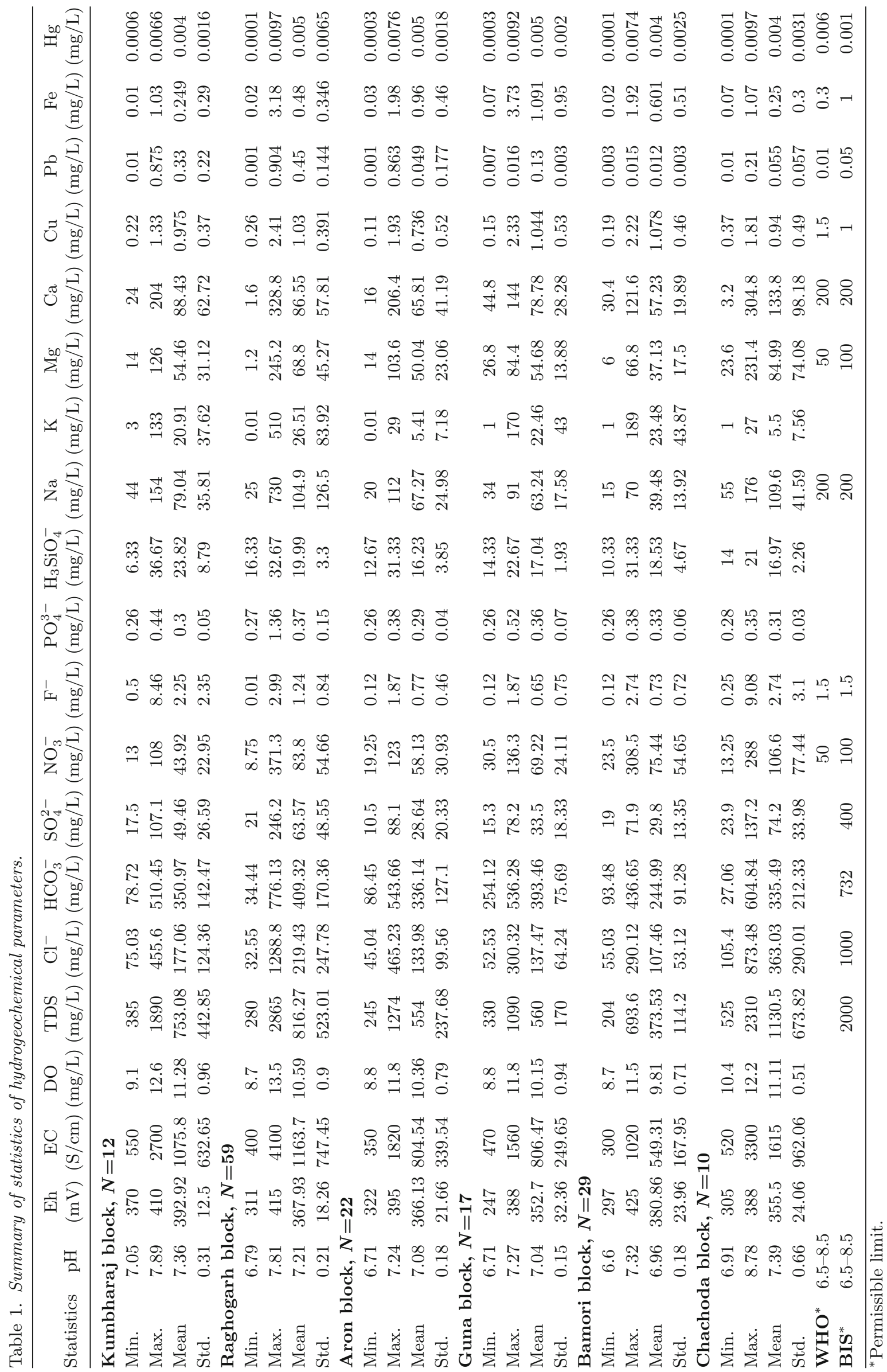


chemical weathering playing a significant role in water chemistry of the Guna district (Drever 1988) (table 1). High DO was observed in almost all blocks of the study area, ranging from 8.7 to $12.9 \mathrm{mg} / \mathrm{L}$ with a mean value of $10.44 \mathrm{mg} / \mathrm{L}$ (table 1). High DO causes oxidizing environment in aquifer system, which influences the redox reaction in confined and semi-confined aquifer systems. High concentrations of $\mathrm{HCO}_{3}^{-}$observed in the study area indicates natural weathering playing an important role in groundwater chemistry (Drever 1988). All blocks of Guna district show lower value of $\mathrm{SO}_{4}^{2-}$ than the permissible limit as BIS (2012) standard $400 \mathrm{mg} / \mathrm{L}$ (table 1). The lower value of standard deviation in almost all blocks except Raghogarh indicates geogenic contribution of $\mathrm{SO}_{4}^{2-}$ (Appelo and Postma 2005). The spatial distribution of $\mathrm{SO}_{4}^{2-}$ in Raghogarh indicates high concentration only in the nearby areas of the sugar industry, which is also less than the permissible limit. Most of the groundwater samples show lower concentrations of $\mathrm{Na}^{+}$and $\mathrm{K}^{+}$than the permissible limit of BIS (2012) and WHO (2004, 2011). Very few samples in Raghogarh block indicate the very high concentration of $\mathrm{Na}^{+}(730 \mathrm{mg} / \mathrm{L})$ and $\mathrm{K}^{+}(510 \mathrm{mg} / \mathrm{L})$ showing anthropogenic input by leaching of NPK fertilizer in Raghogarh block, justified by assessing the spatial distribution (Jalali 2009) (figure 9a). The high concentration phosphate in Raghogarh block is observed due to intensive agricultural activities performed and excess use of fertilizers (MP Government 2012). No known phosphate mineral rocks were reported in the study area (Wadia 1981).

\subsection{Hydrogeochemical evaluation}

The geochemistry of groundwater can be easily understood by applying the $\mathrm{X}-\mathrm{Y}$ plot of various geochemical species (Guler et al. 2002). The geochemical variation in the aquifer is interdependent on the various ions; because they play a very important role in various hydrogeochemical processes (ion exchange, oxidation-reduction, evaporation and adsorption) occurring in the confined and semi-confined aquifer at a certain temperature and $\mathrm{pH}$ condition. The major ions [cations $\left(\mathrm{Na}^{+}, \mathrm{Ca}^{2+}, \mathrm{K}^{+}, \mathrm{Mg}^{2+}\right)$ and anions $\left(\mathrm{Cl}^{-}, \mathrm{SO}_{4}^{2-}\right.$, $\left.\mathrm{HCO}_{3}^{-}\right)$] are those ions whose concentration surpasses $10 \%$ of the molar concentration in the solution (Guler et al. 2002). The hydrogeochemical facies were calculated by converting major ions concentrations $(\mathrm{meq} / \mathrm{L})$ into the percentage, which helps in determining water-types of the study area (Guler et al. 2002). Piper diagram was used to understand the hydrogeochemical evaluation of groundwater. Hydrogeochemical facies shows decreasing order of cation hydrogeochemical facies like $\mathrm{Mg}^{2+}>\mathrm{Ca}^{2+}>\mathrm{Na}^{+}>\mathrm{K}^{+}(40.27 \%)$, $\mathrm{Ca}^{2+}>\mathrm{Mg}^{2+}>\mathrm{Na}^{+}>\mathrm{K}^{+}(19.46 \%), \quad \mathrm{Mg}^{2+}>\mathrm{Na}^{+}>$ $\mathrm{Ca}^{2+}>\mathrm{K}^{+} \quad(14.77 \%), \quad \mathrm{Na}^{+}>\mathrm{Mg}^{2+}>\mathrm{Ca}^{2+}>\mathrm{K}^{+}$ (11.41\%), $\mathrm{Na}^{+}>\mathrm{Ca}^{2+}>\mathrm{Mg}^{2+}>\mathrm{K}^{+}(9.40 \%), \mathrm{Ca}^{2+}>$ $\mathrm{Mg}^{2+}>\mathrm{K}^{+}>\mathrm{Na}^{+}(1.34 \%), \mathrm{Ca}^{2+}>\mathrm{Na}^{+}>\mathrm{Mg}^{2+}>\mathrm{K}^{+}$ (0.67\%), $\mathrm{Ca}^{2+}>\mathrm{K}^{+}>\mathrm{Mg}^{2+}>\mathrm{Na}^{+}(0.67 \%), \mathrm{Mg}^{2+}>$ $\mathrm{K}^{+}>\mathrm{Ca}^{2+}>\mathrm{Na}^{+}(0.67 \%), \mathrm{Ca}^{2+}>\mathrm{K}^{+}>\mathrm{Na}^{+}>\mathrm{Mg}^{2+}$ $(0.67 \%), \mathrm{K}^{+}>\mathrm{Ca}^{2+}>\mathrm{Mg}^{2+}>\mathrm{Na}^{+}(0.67 \%)$ (figure 2$)$. The high presence of alkaline earth metal cations facies indicates the dominance of natural weathering over anthropogenic input with few exceptions may be due to anthropogenic input, i.e., leaching of fertilizer from agriculture land, industrial effluent (Guler et al. 2002; Appelo and Postma 2005; Srivastava and Ramanathan 2008). Most of the samples show decreasing order of anion hydrogeochemical facies as $\mathrm{HCO}_{3}^{-}>\mathrm{Cl}^{-}>\mathrm{SO}_{4}^{2-}$, while a few samples showed different trends indicating some localized change in water quality due to anthropogenic input. The hydrogeochemical facies based on anion concentration (meq/L) in groundwater shows $\mathrm{HCO}_{3}^{-}>\mathrm{Cl}^{-}>\mathrm{SO}_{4}^{2-}(72.48 \%)$, $\mathrm{Cl}^{-}>\mathrm{HCO}_{3}^{-}>\mathrm{SO}_{4}^{2-}$ (25.50\%) and $\mathrm{Cl}^{-}>\mathrm{SO}_{4}^{2-}>$ $\mathrm{HCO}_{3}^{-}(2.01 \%$ ) (figure $2 \mathrm{a}$ ). It also shows water chemistry of most of the groundwater controlled by natural weathering, while significant contribution of anthropogenic source is observed in few groundwater samples. This is also justified by Chadha diagram (figure $2 \mathrm{~b}$ ).

The Chadha diagram was used to define major water-types in the study area, and it helps to understand the role of major ions (both cations and anions) in water chemistry (figure $2 \mathrm{~b}$ ). It is one of the modified versions of the Piper diagram and plots the difference in meq.\% $\left[\left(\mathrm{Ca}^{2+}+\right.\right.$ $\left.\left.\mathrm{Mg}^{2+}\right)-\left(\mathrm{Na}^{+}+\mathrm{K}^{+}\right)\right]$on $\mathrm{X}$-axis and difference in meq.\% $\left[\left(\mathrm{HCO}_{3}^{-}\right)-\left(\mathrm{SO}_{4}^{2-}+\mathrm{Cl}^{-}\right)\right]$on $\mathrm{Y}$-axis (Ako et al. 2014). The rectangular field observed in this plot looks similar to the diamond-shaped filed in Piper diagram and it helps to understand watertypes and water chemistry of the study area. As similar to Piper diagram, eight fields in the rectangular plot represents eight different water-types. These are (a) alkali metals dominating, (b) alkaline earth-metals dominating, (c) bicarbonate dominating, (d) sulphate and chloride dominating, (e) alkali metals and bicarbonate dominating, (f) alkaline 
(a)

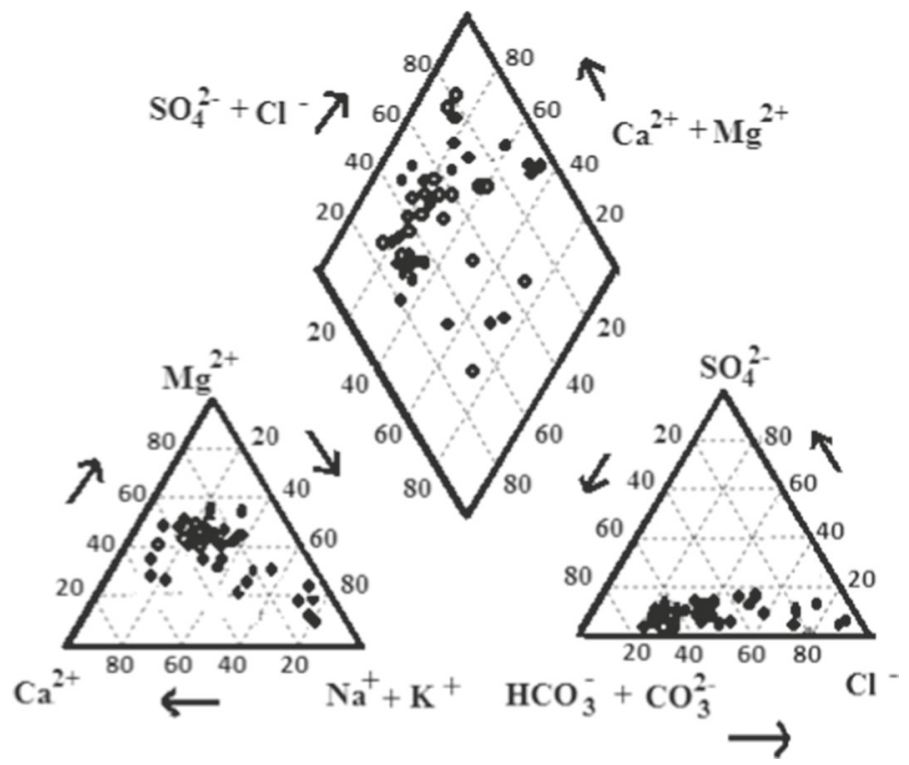

(b)

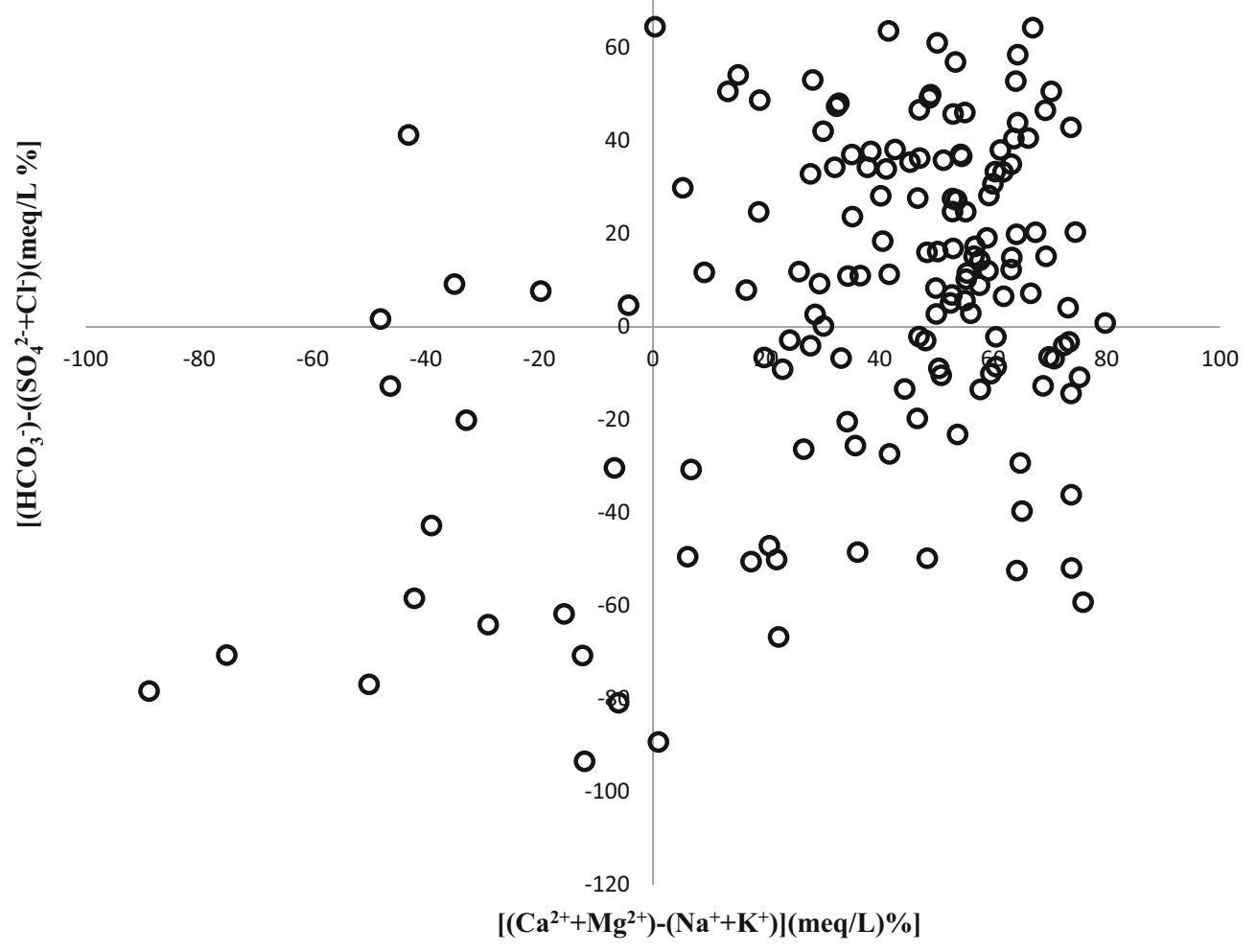

Figure 2. Geochemical classification of groundwater (a) Piper diagram and (b) Chadha diagram.

earth-metals and bicarbonate dominating, (g) alkaline earth-metals, sulphate and chloride dominating, and (h) alkali metals, sulphate and chloride dominating (Chadha 1999). It indicates $\sim 59.73 \%$ of groundwater are $\mathrm{Ca}-\mathrm{Mg}-\mathrm{HCO}_{3}$ water-types, $\sim 28.19 \%$ samples $\mathrm{Ca}-\mathrm{Mg}-\mathrm{SO}_{4}-\mathrm{Cl}$ water-types, $\sim 8.72 \%$ samples $\mathrm{Na}-\mathrm{K}-\mathrm{SO}_{4}-\mathrm{Cl}$ water-types and $3.36 \%$ groundwater $\mathrm{Na}-\mathrm{K}-\mathrm{HCO}_{3}$ water-types (figure 2b). The dominance of $\mathrm{Ca}-\mathrm{Mg}-\mathrm{HCO}_{3}$ water-type in the study indicates groundwater either contain waters in the primary stage of geochemical evolution (recent recharge) or rapidly 


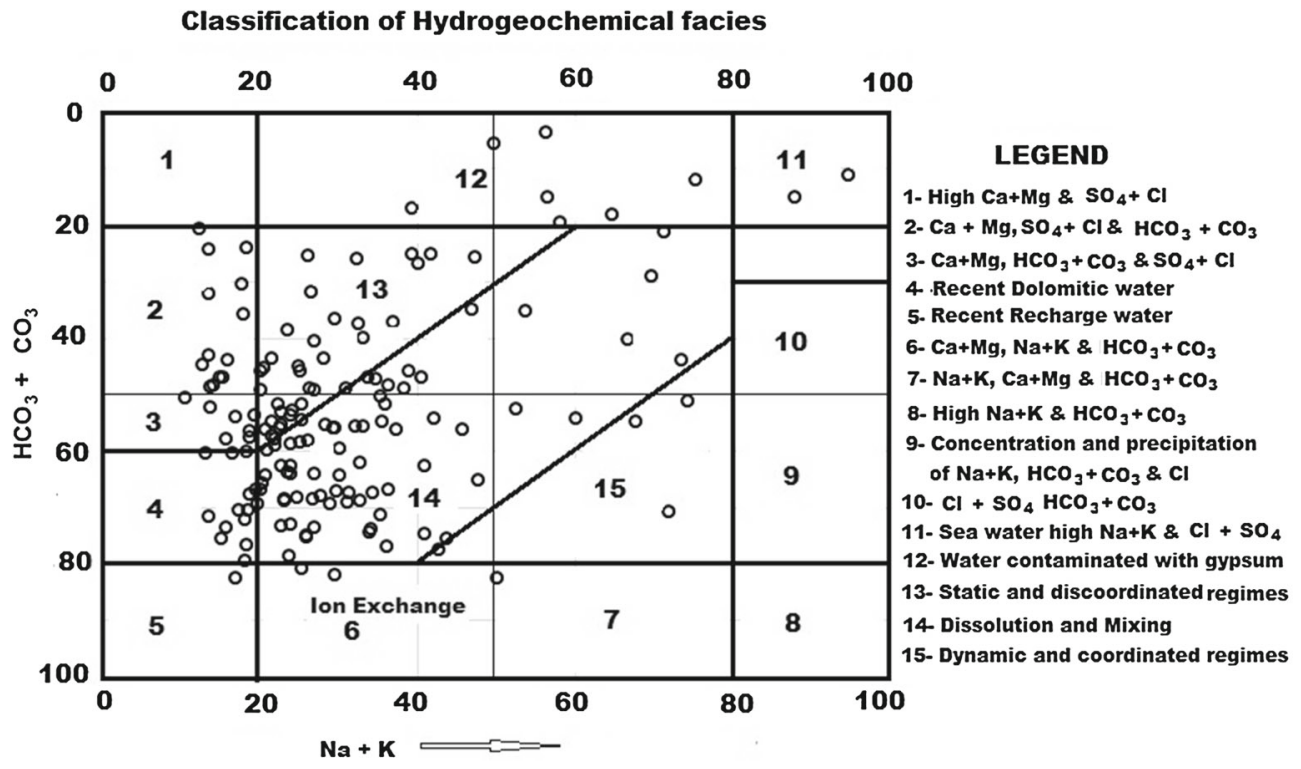

Figure 3. Classification of hydrogeochemical facies (reconstructed diamond field of Piper diagram by Lawrence and Balasubramanian 1994).

circulating groundwater which have not involved in the rock-water interaction (Kebede et al. 2005; Akao et al. 2011; Marghade et al. 2011).

The water classification of hydrogeochemical facies of Piper diagram was reconstructed by Lawrence and Balasubramanian (1994) in the new reconstructed diamond field (figure 3). It classified water in the various zones on the basis of various reactions occurring in the groundwater aquifer system (figure 3). The reconstructed diamond field shows $43.51 \%$ of groundwater samples are in active dissolution mixing zone, $\sim 23.38 \%$ groundwater samples are in static and disco-ordinated zone, $\sim 9.04 \%$ groundwater samples shows recent dolomitic water, $\sim 8.44 \%$ groundwater samples shows $\mathrm{Ca}-\mathrm{Mg}-\mathrm{SO}_{4}-\mathrm{Cl}-\mathrm{HCO}_{3}$ hydrogeochemical facies, $\sim 4.55 \%$ groundwater samples shows $\mathrm{Ca}^{2+}$ $\mathrm{Mg}^{2+}-\mathrm{HCO}_{3}^{-}-\mathrm{SO}^{2+}{ }_{-} \mathrm{Cl}^{-}$hydrogeochemical facies, $\sim 4.55 \%$ samples shows contaminated with gypsum, $\sim 2.6 \%$ samples shows dynamic and coordinated regime, $\sim 1.3 \%$ samples shows $\mathrm{Ca}^{2+}-\mathrm{Mg}^{2+}-\mathrm{Na}^{+}-$ $\mathrm{K}^{+}-\mathrm{HCO}_{3}^{-}$hydrogeochemical facies and $1.3 \% \mathrm{Na}^{+}-$ $\mathrm{K}^{+} \mathrm{Cl}^{-} \mathrm{SO}_{4}^{2-}$ hydrogeochemical facies (figure 3 ).

\subsection{Water classification}

The water quality of the study area was assessed on the basis of various statistics suggested by worldwide researchers. The water quality index (WQI) calculated for the study area on the basis of weight for each hydrogeochemical parameters and standard permissible limit as recommended by BIS (2012) (table 2). The statistics of WQI of study area indicate $\sim 22.81 \%$ samples are goodwater; $\sim 71.14 \%$ samples are poor-water, $\sim 5.37 \%$ very poor-water and $0.67 \%$ unsuitable for drinking purpose. The calculated WQI values were used in this study to classify the water in five categories (Batabyal and Chakraborty 2015). These are (a) excellent-water (WQI $<50)$; (b) goodwater (WQI $=50-100)$; (c) poor-water (WQI = $100-200) ;(d)$ very poor-water (WQI $=200-300$ ) and (e) water unsuitable for drinking purpose (WQI > 300).

Wilcox (1955) has classified water in five divisions for suitability of the irrigation on the basis of EC and soluble sodium percentage (SSP) in water. Based on the EC, $\sim 44.97 \%$ of groundwater are good, $\sim 50.34 \%$ groundwater under permissible and $4.7 \%$ groundwater in doubtful. On the basis of SSP, $\sim 38.26 \%$ groundwater excellent, $\sim 44.97 \%$ good, $\sim 10.07 \%$ permissible, $\sim 5.37 \%$ in doubtful and $1.34 \%$ groundwater unsuitable for irrigation. Eaton (1950) has classified water in two categories on the basis of SSP. As per Eaton classification, $\sim 93.29 \%$ of groundwater samples is safe, while $\sim 6.71 \%$ groundwater samples are unsafe for irrigation. SSP is calculated by following equation (Wilcox 1955).

$$
\mathrm{SSP}=\frac{\text { Soluble sodium concentration } \times 100}{\text { Total cation concentration }} .
$$

Stuyfzand (1989) has classified water in eight divisions for suitability on the basis of chloride 
Table 2. Relative weight of hydro-geochemical parameters.

\begin{tabular}{lccc}
\hline $\begin{array}{l}\text { Chemical } \\
\text { parameters }\end{array}$ & $\begin{array}{c}\text { Indian standard } \\
\text { (desirable limit) }\end{array}$ & $\begin{array}{c}\text { Weight } \\
\left(w_{i}\right)\end{array}$ & $\begin{array}{c}\text { Relative weight } \\
\left(W_{i}\right)\end{array}$ \\
\hline $\mathrm{pH}$ & $6.5-8.5$ & 4 & 0.0714 \\
$\mathrm{TDS}(\mathrm{mg} / \mathrm{L})$ & $500-2000$ & 4 & 0.0714 \\
$\mathrm{Cl}^{-}(\mathrm{mg} / \mathrm{L})$ & $250-1000$ & 3 & 0.0536 \\
$\mathrm{HCO}_{3}^{-}(\mathrm{mg} / \mathrm{L})$ & $244-732$ & 3 & 0.0536 \\
$\mathrm{SO}_{4}^{2-}(\mathrm{mg} / \mathrm{L})$ & $200-400$ & 4 & 0.0714 \\
$\mathrm{NO}_{3}^{-}(\mathrm{mg} / \mathrm{L})$ & $45-100$ & 5 & 0.0893 \\
$\mathrm{~F}^{-}(\mathrm{mg} / \mathrm{L})$ & $1-1.5$ & 5 & 0.0893 \\
$\mathrm{Mg}^{2+}(\mathrm{mg} / \mathrm{L})$ & $30-100$ & 2 & 0.0357 \\
$\mathrm{Ca}^{2+}(\mathrm{mg} / \mathrm{L})$ & $75-200$ & 2 & 0.0357 \\
$\mathrm{Fe}^{2+}(\mathrm{mg} / \mathrm{L})$ & $0.3-1.0$ & 4 & 0.0714 \\
$\mathrm{~Pb}^{2+}(\mathrm{mg} / \mathrm{L})$ & $0.01-0.05$ & 5 & 0.0893 \\
$\mathrm{Hg}^{2+}(\mathrm{mg} / \mathrm{L})$ & 0.001 & 4 & 0.0893 \\
$\mathrm{Cu}^{2+}(\mathrm{mg} / \mathrm{L})$ & $0.05-1.5$ & 2 & 0.0714 \\
$\mathrm{Alkalinity}(\mathrm{mg} / \mathrm{L})_{\mathrm{Hardness}(\mathrm{mg} / \mathrm{L})}^{200-600}$ & 2 & 0.0357 \\
\hline
\end{tabular}

concentration in water. Based on $\mathrm{Cl}^{-}$ concentration $\sim 27.52 \%$ groundwater samples are very fresh, $\sim 47.65 \%$ groundwater fresh, $\sim 13.42 \%$ fresh-brackish, $\sim 10.74 \%$ brackish and $0.67 \%$ samples brackish salt category.

Richard (1954) has classified water on the basis of sodium adsorption ratio (SAR). SAR of these groundwater samples were calculated by given formula

$$
\mathrm{SAR}=\frac{\mathrm{Na}^{+}}{\sqrt{\left(\mathrm{Ca}^{2+}+\mathrm{Mg}^{2+}\right) / 2}} .
$$

According to Richard classification, SAR of $\sim 97.99 \%$ groundwater are in excellent condition $(<10), \sim 1.34 \%$ groundwater good condition (1018 ) and $0.67 \%$ groundwater unfair (18-26) for irrigation.

Residual sodium carbonate (RSC) was first time proposed by Eaton (1950). RSC can be calculated by the following equation

$$
\mathrm{RSC}=\left[\left(\mathrm{CO}_{3}^{2-}+\mathrm{HCO}_{3}^{-}\right)-\left(\mathrm{Ca}^{2+}+\mathrm{Mg}^{2+}\right)\right] .
$$

Richard (1954) has classified water on the basis of RSC in three divisions. On the basis of RSC $\sim 95.97 \%$ of groundwater is good for irrigation, $\sim 3.36 \%$ groundwater moderate for irrigation and $0.67 \%$ groundwater bad for irrigation. USSL (1954) has classified water on the basis of TDS in four divisions. Around $38.93 \%$ of groundwater samples show TDS in the range of $200-500 \mathrm{mg} / \mathrm{L}, \sim 56.38 \%$ groundwater shows TDS in the range of 500-1500 and $4.7 \%$ groundwater indicate TDS $>1500 \mathrm{mg} / \mathrm{L}$.
Ryzner (1944) has proposed a corrosive index to evaluate the corrosive tendency of groundwater towards metallic pipes. The corrosive analysis of groundwater of the Guna district indicate almost all samples can corrode the metallic pipes. Hence, PVC pipe should be preferred for the supply of groundwater for both irrigation and drinking purpose. Further, this corrosiveness also accelerated by high DO (observed in groundwater) can cause rusting, while high carbonate and bicarbonate cause caustic embrittlement in the metal pipe (Ryzner 1944).

\subsubsection{Schoeller diagram}

The Schoeller $(1955,1977)$ semi-logarithm diagram was used in this study for representing all the major ions in the single graph. The Schoeller diagram shows alkaline earth-metal carbonates $\left[\mathrm{Ca}\left(\mathrm{HCO}_{3}\right)_{2}, \mathrm{CaCO}_{3}, \mathrm{Mg}\left(\mathrm{HCO}_{3}\right)_{2}, \mathrm{MgCO}_{3}\right]$ are dominating in groundwater samples of the Guna district with few exceptions; where chloride ions available in significant amount indicate anthropogenic influence in few samples. As per Schoeller diagram the major cations in groundwater are available as $\mathrm{Mg}^{2+}>\mathrm{Ca}^{2+}>\mathrm{Na}^{+}>\mathrm{K}^{+}$, while anions are as follows $\mathrm{HCO}_{3}^{-}>\mathrm{Cl}^{-}>\mathrm{SO}_{4}^{2-}$ (figure 4). The Scholler diagram indicates geogenic process is mainly controlling the groundwater chemistry (Drever 1988).

\subsubsection{Salinity diagram}

The salinity diagram is first time used by Wilcox (1955) for classification of water. He discussed 


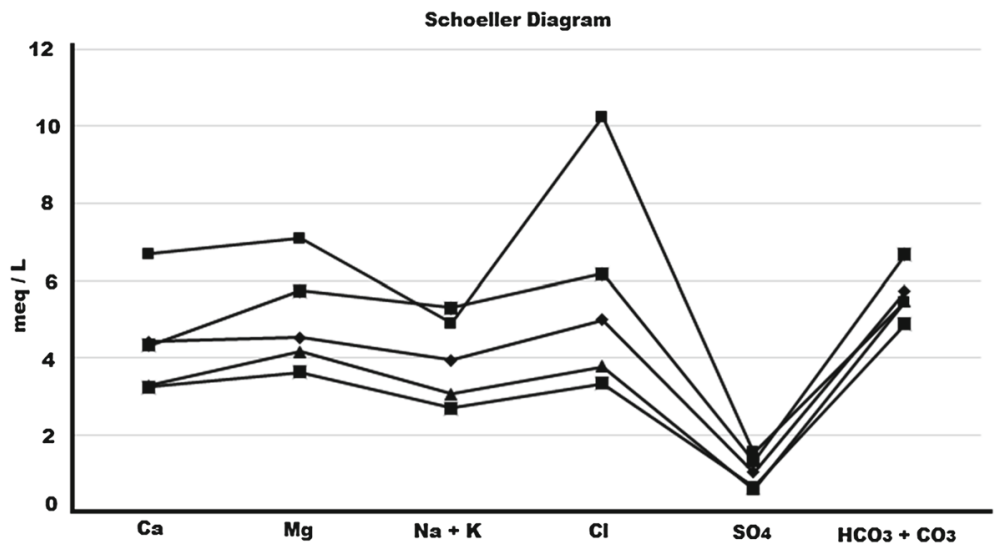

Figure 4. Schoeller diagram of the study area.

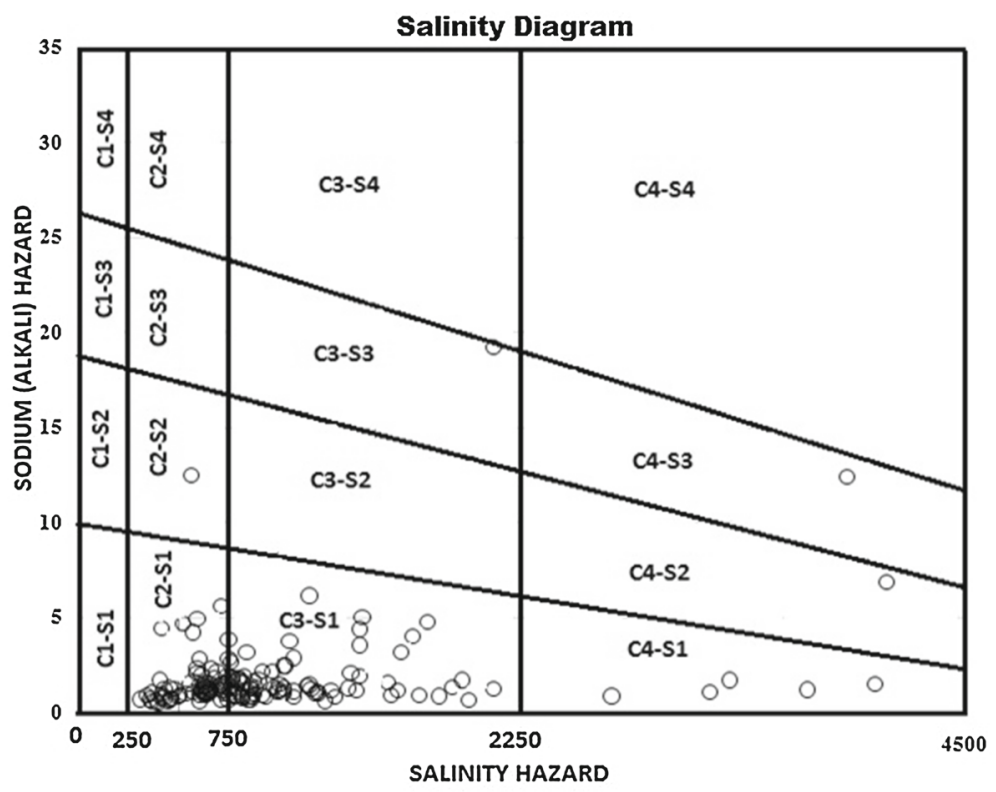

Figure 5. USSL diagram for classification of groundwater for irrigation purpose.

the importance of salinity diagram for suitability of the water for irrigation purpose, on the basis of sodium-hazard and salinity-hazard. The salinity diagram of the study area indicates $\sim 44.30 \%$ groundwater in low sodium-hazard (S1) and medium salinity-hazard (C2), i.e., falls under the C2S1 classification of salinity diagram (figure 5). It indicates water can be used for irrigation considering the sodium-hazard but on the basis of salinity, it can be used, if a moderate amount of leaching occurs. The salinity diagram also shows $\sim 49.66 \%$ groundwater fall under C3S1 classification indicating that the groundwater can be used for irrigation on the basis of SAR, but cannot be used on soil with restricted drainage on the basis of salinity (figure 5 ). Similarly, $\sim 3.36 \%$ groundwater fall under C4S1 category, while $\sim 0.67 \%$ groundwater falls under C2S2, C3S3, C4S3, and C4S2 each category. Around $2.68 \%$ groundwater unsuitable for irrigation on the basis of salinity diagram either due to high salinity-hazard or high sodium-hazard (figure 5).

\subsubsection{Doneen diagram}

Doneen (1964) has classified groundwater in three classes (I, II and III) for suitability of water for irrigation purpose on the basis of permeability index (figure 6). The permeability index (PI) was calculated by using the formula as given below:

Permeability index $(\mathrm{PI})=\frac{\left(\mathrm{Na}+\sqrt{\mathrm{HCO}_{3}}\right) \times 100}{(\mathrm{Ca}+\mathrm{Mg}+\mathrm{Na})}$. 


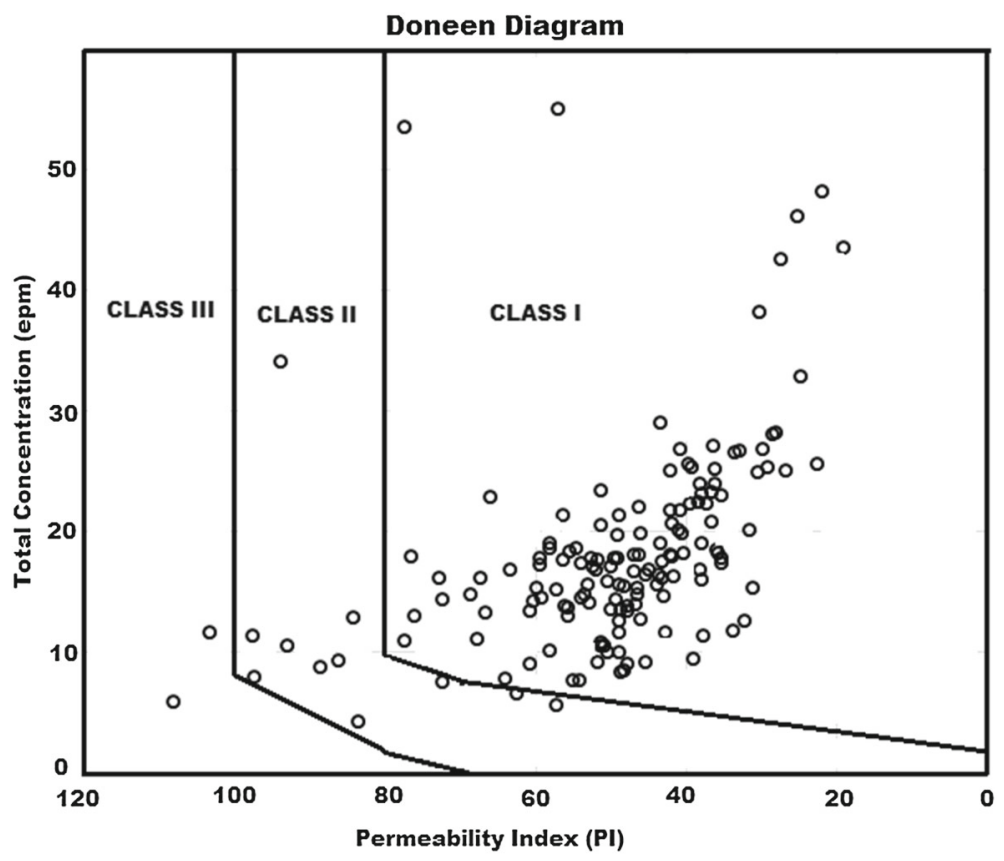

Figure 6. Classification of groundwater for suitability of irrigation (Doneen plot, 1964).

The Doneen diagram shows $\sim 91.56 \%$ of groundwater fall under Class I, $\sim 7.14 \%$ of groundwater fall under Class II and $1.30 \%$ ground-water fall under Class III of Doneen classification (figure 6). Around $91.56 \%$ groundwater show higher permeability of the soil and hence lower drainage problems, while $1.3 \%$ groundwater show lower permeability of the soil and higher drainage problems. Approximately $7.14 \%$ groundwater show medium permeability and medium drainage problems (figure 6).

\subsection{Statistical analysis}

The statistical analysis of hydrogeochemical data was carried out with an objective to understand the geochemical process occurring in-situ of groundwater aquifer system. The two statistical method correlation and factor analysis are widely used to understand the geochemical modeling of chemical parameters (Lawrence and Upchurch 1982; Balasubramanian et al. 1985). The correlation matrix of groundwater samples collected from study area is shown in table 3. A good correlation between TDS and other major ions $\mathrm{Cl}^{-}(0.93), \mathrm{SO}_{4}^{2-}(0.85), \mathrm{Ca}^{2+}$ (0.83), EC (0.95), hardness (0.85) were observed, which indicates these ions are controlling chemistry of the groundwater (Appelo and Postma 2005). It also indicates the possibility of anthropogenic input or high rate of evapotranspiration (Drever 1988; Karnath 1991; Ako et al. 2014).
EC shows average correlation with $\mathrm{Mg}^{2+}(0.67)$, $\mathrm{Na}^{+}$(0.61), $\mathrm{NO}_{3}^{-}(0.60), \mathrm{K}^{+}(0.50)$ and $\mathrm{HCO}_{3}^{-}$ (0.44) indicating anthropogenic input in groundwater (Aiuppa et al. 2003). Good correlation of $\mathrm{Na}^{+}$with $\mathrm{Cl}^{-}(0.70)$ and moderate correlation with EC (0.61) and TDS (0.61) indicates the dominance of evapotranspiration or anthropogenic input (Appelo and Postma 2005; Akao et al. 2014). Nitrate showed moderate correlation with $\mathrm{K}^{+}$(0.63), $\mathrm{Ca}^{2+}$ (0.63), $\mathrm{Mg}^{2+}(0.47)$ and $\mathrm{PO}_{4}^{3-}$ (0.48) indicating anthropogenic input in groundwater aquifer, may be through leaching of fertilizer from agriculture lands during farming activities (Jalali 2009). The good correlation of $\mathrm{Cl}^{-}$with $\mathrm{SO}_{4}^{2-}(0.83), \mathrm{Na}^{+}(0.70), \mathrm{Ca}^{2+}(0.74)$ and hardness $(0.74)$ indicate anthropogenic input in groundwater (Drever 1988). Chloride showing moderate correlation with $\mathrm{NO}_{3}^{-}(0.50), \mathrm{K}^{+}(0.51)$ and $\mathrm{Mg}^{2+}$ (0.56) supports anthropogenic input (Jalali 2009). The inverse relationship between nitrate concentration and aquifer depth are also observed to indicate leaching of nitrate from agriculture land or another industrial effluent (figure 9b) (Spalding and Exner 1993; Ray and Schock 1996; Akao et al. 2011). Bicarbonate ions showed good correlation with alkalinity $(0.81), \mathrm{Mg}^{2+}(0.70)$ and hardness (0.61) indicating a common source of origin (Ranjan et al. 2017). It showed moderate correlation with $\mathrm{Ca}^{2+}(0.46)$ indicating that it is available mainly as $\mathrm{Mg}\left(\mathrm{HCO}_{3}\right)_{2}$ in the groundwater. Fluoride showed a poor correlation with 


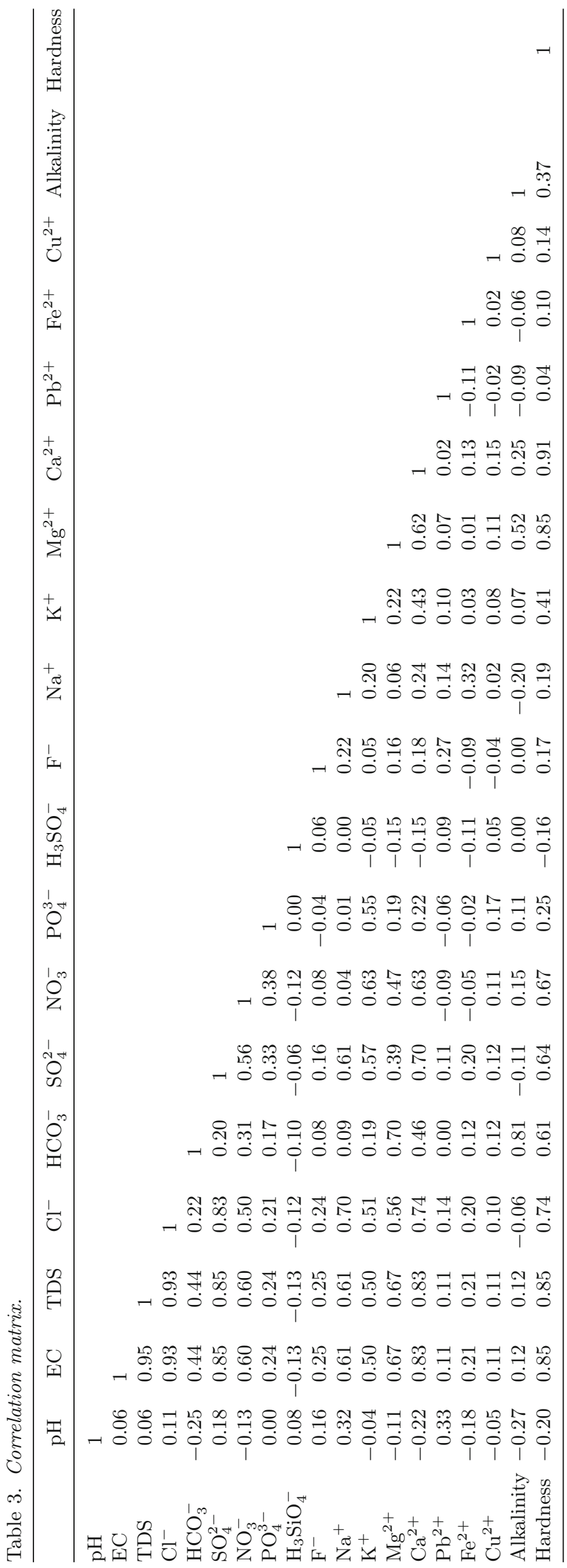

$\mathrm{Pb}^{2+}$ (0.27), $\mathrm{Na}^{+}$(0.22), $\mathrm{Ca}^{2+}(0.18), \mathrm{Mg}^{2+}(0.16)$, $\mathrm{Cl}^{-}$(0.24) indicate other source of origin (Srivastava and Ramanathan 2008). The poor relation between fluoride with $\mathrm{Ca}^{2+}$ and $\mathrm{Mg}^{2+}$ is a result of variation in precipitation and solubility activities of $\mathrm{Ca}$ and $\mathrm{Mg}$-rich minerals in groundwater (Hem 1991; Subba Rao et al. 2016).

\subsection{Fluoride enrichment}

The statistics of fluoride concentration in all the six blocks of the Guna district is given in table 1 . The spatial distribution of $\mathrm{F}^{-}$indicates enrichment occurs primarily in Kumbharaj and Chachoda block, which are geologically dominated by basaltic rocks (figure 7a). These blocks of the study area also contained fluoride-rich in minerals (Handa 1975; Wadia 1981). Most of the central area of the Guna district shows low concentration (figure 7a). Western portion (very close to Rajasthan Border) of the study area shows higher value due to the presence of fluorine-rich minerals, i.e., amphiboles, illuminates, mica and apatite (Handa 1975; Wadia 1981). The variations in the spatial distribution of fluoride content in groundwater indicates local influence over fluoride distribution, the relative abundance of fluoride-rich rock minerals, residence time and degree of weathering (figure 7a). The variation of fluoride with depth is not so significant indicating that the major source of fluoride in groundwater is geogenic in nature (figure $7 \mathrm{~b}$ ). The fluoride concentration in groundwater of Kumbharaj (0.50-8.46 mg/L), Raghogarh (0.01-2.99 mg/L), Aron (0.12-1.87 mg/L), Guna (0.12-1.87 mg/L), Bamori $(0.12-2.74 \mathrm{mg} / \mathrm{L})$ and Chachoda (0.25-9.08 mg/L) blocks are higher than the permissible limit $(1.5 \mathrm{mg} / \mathrm{L})$ for drinking water (WHO 2004, 2011). Excess intake of $\mathrm{F}^{-}$in drinking water can cause health hazard like skeletal and dental fluorosis in human being and equally affect other vertebrates and mammals. The fluorosis causes dissolution of calcium available in bones and teeth and formed $\mathrm{CaF}_{2}$ (Sajil Kumar et al. 2014). The skeletal fluorosis can cause damage to human bone and teeth which is largely composed of calcium.

$$
\text { Ca-Bone }+ \text { Fluoride }+\mathrm{H}^{+} \longrightarrow \mathrm{CaF}_{2} \text {. }
$$

The major source of fluoride in groundwater is geogenic, i.e., leaching of fluoride through mineral rocks containing fluorine as an ingredient in the hard-rock aquifer (Sajil Kumar 2017). The 


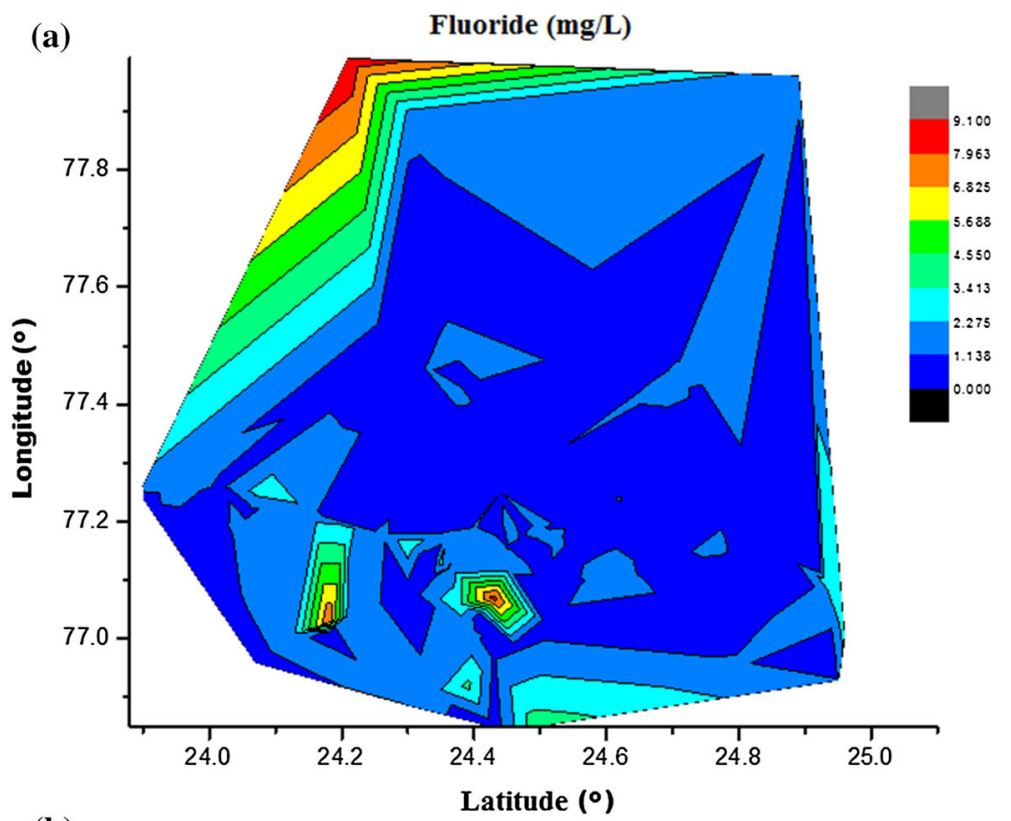

(b)

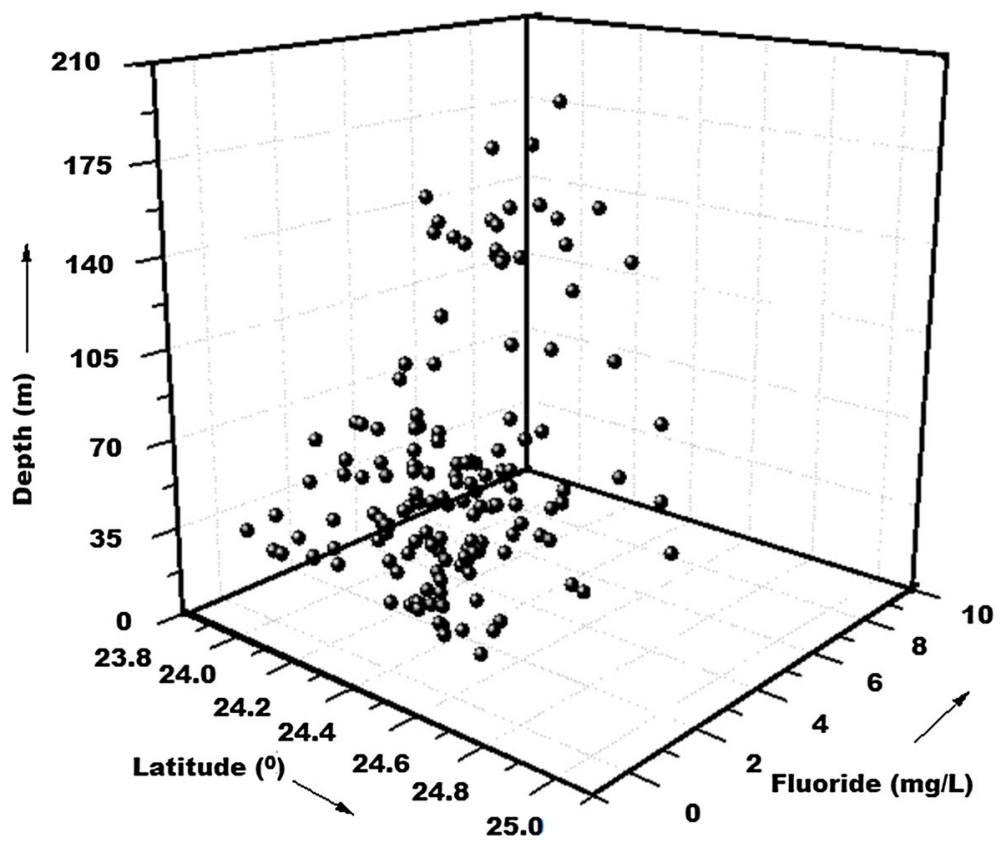

Figure 7. (a) Spatial distribution of fluoride in groundwater in the study area. (b) Distribution of fluoride in groundwater with depth below subsurface.

availability of fluoride-rich minerals (e.g., amphiboles, illuminates, mica and apatite) in Guna district may be one of the major reasons for the enrichment of fluoride in groundwater (Handa 1975; Wadia 1981). The chemistry behind enrichment of $\mathrm{F}^{-}$in groundwater also depends on residence time of water in confined and semiconfined aquifers (high residence times support dissolution of minerals) and the way it is mobilized from fluoride-rich rock minerals to the aquifer (Appelo and Postma 2005). There are various factors which influence the kinetics of mobilization of fluoride from rock minerals for the enrichment of groundwater aquifer in both confined and semiconfined hard-rock aquifers. The factors which influence the kinetics of enrichment of fluoride in the hard-rock aquifer of the study area are the geology of study area, $\mathrm{pH}$, porosity, structure of aquifer, anion exchange capacity of aquifer, minerals, residence time, groundwater age, concentration of $\mathrm{CO}_{3}^{2-}$ and $\mathrm{HCO}_{3}^{-}$in groundwater (Apambire et al. 1997) 


$$
\mathrm{CaCO}_{3}+\mathrm{H}^{+}+2 \mathrm{~F}^{-} \longrightarrow \mathrm{CaF}_{2}+\mathrm{HCO}_{3}^{-} \text {. }
$$

The $\mathrm{CaF}_{2}$ precipitates out because the solubility product of $\mathrm{Ca}^{2+}$ is much higher than the $\mathrm{CaF}_{2}$, so in presence of $\mathrm{Ca}^{2+}$ ion the dissolution of $\mathrm{F}^{-}$is suppressed by $\mathrm{Ca}^{2+}$ hence decreases $\mathrm{F}^{-}$ concentration groundwater (Handa 1975; Appelo and Postma 2005). Further in the study area, an easy circulation of water due to intense and longterm irrigation practice in soil/weathered zone accelerate the alkalinity more effectively (Wodeyar and Sreenivasan 1996; Madhnure et al. 2007; Subba Rao et al. 2016). Fluoride can work as strong ligand in groundwater and can form soluble complexes with polyvalent cations $\left(\mathrm{Mg}^{2+}\right.$, $\mathrm{Fe}^{3+}, \mathrm{Al}^{3+}, \mathrm{Ca}^{2+}$ ) at various $\mathrm{pH}$ of water (Nordstrom and Jenne 1977), e.g., fluorapatite dissolution rates decreased at $\mathrm{pH} \geq 3$, remained constant between $7 \leq \mathrm{pH} \leq 10$ and decreased again at $\mathrm{pH} \geq 10$ (Chaïrat et al. 2007). Most of the ground-water samples show $\mathrm{pH}$ in the range of 6.7-8.78 in Guna district. This alkaline condition is a favourable condition for dissolution of fluoride-rich rock minerals (Stumm and Morgan 1996). The high calcium concentration favours precipitation of fluoride as $\mathrm{CaF}_{2}$. The low concentration of $\mathrm{Ca}^{2+}$ favours higher dissolution of $\mathrm{CaF}_{2}$ from the source material to compensate for the requirement of $\mathrm{Ca}^{2+}$ in chemical equilibria (equation (7); Freeze and Cherry 1979; Guo et al. 2007; Subba Rao et al. 2016). The bivariate plot between $\mathrm{EC}$ and $\mathrm{F}^{-}$also shows poor correlation $\left(r^{2}=0.078\right)$, which indicates the contribution of fluoride in EC of groundwater is insignificant, may be due to the low concentration of fluoride in comparison to other major ions in groundwater (table 1). The bivariate plot between $\mathrm{HCO}_{3}^{-}$vs. $\mathrm{F}^{-}$shows poor correlation $\left(r^{2}=0.080\right)$ indicating equation (7) in equilibrium since $\mathrm{pH}$ of water is in the range of 6.7-8.4 (Chaïrat et al. 2007). The chemical weathering of rock minerals causes the release of $\mathrm{Na}^{+}$ and $\mathrm{HCO}_{3}^{-}$ions. Ion-exchange between $\mathrm{Na}^{+}$and $\mathrm{Ca}^{2+}$ and precipitation of $\mathrm{CaCO}_{3}$ reduces the activity of $\mathrm{Ca}^{2+}$ ion. This favours dissolution of $\mathrm{CaF}_{2}$ from fluoride-rich minerals present in the host rocks, leaching to the higher concentration of $\mathrm{F}^{-}$in groundwater. The positive correlation between $\mathrm{F}^{-}$and $\mathrm{Mg}^{2+}$ indicate groundwater associated with the granitic terrain of Western India (Subba Rao et al. 2016) (figure 8). The $\mathrm{Na} / \mathrm{Cl}$ ratio $(>1)$ indicate $\sim 40 \%$ samples fresh ground water, $\sim 10 \%$ indicate dissolution of halite $(\mathrm{Na} / \mathrm{Cl}=$
1) and around $70 \%$ samples indicate mixing of groundwater and saline water $(\mathrm{Na} / \mathrm{Cl}>0.86)$ (figure 8) (Vengosh and Rosenthal 1994; Ako et al. 2014).

\subsection{Nitrate contamination}

The statistics of $\mathrm{NO}_{3}^{-}$concentration in all the six blocks of Guna district are given in table 1 . The spatial distribution of nitrate in groundwater of the Guna district shows most of the Central Guna possess nitrate concentration in the range of 8-99 mg/L (figure 9a). Nitrate distributions also indicate that the Raghogarh block is maximum contaminated in comparison to other blocks of Guna district may be due to the presence of National Fertilizer Limited (NFL), which causes nitrate contamination in groundwater of the Raghogarh block along with fertilizer used in agriculture fields during farming of various crops (figure 9a). Geographically NFL, India is located in the Raghogarh block, where the significant concentration of $\mathrm{NO}_{3}^{-}$was observed in comparison to other blocks may be due to leaching through effluent or sink of the fertilizer industry. The probability of leaching is also indicated in the annual report of CGWB (2013). It also indicates nitrate contribution in groundwater by an anthropogenic source of fertilizer used (in this case $30-35 \mathrm{~kg}$ urea/ha) in the agriculture field, sewage waste, fertilizer industry (Jalali 2009; Akao et al. 2014). Nitrate concentration in groundwater samples of Kumbharaj (13.0-108.0 mg/L), Raghogarh (8.75$371.25 \mathrm{mg} / \mathrm{L})$, Aron (19.25-123.0 mg/L), Guna (30.50-136.25 mg/L), Bamori (23.50-308.50 mg/L) and Chachoda (13.25-288.50 mg/L) blocks indicates anthropogenic influence on groundwater (table 1). These areas are rich for agricultural activities. A very small zone near NFL indicates high concentration of nitrate, which in turn indicates NFL works as a point source (figure 9a). The nitrate concentration decreases with depth indicating $\mathrm{NO}_{3}^{-}$contamination is mainly in shallow aquifer may be due to leaching of fertilizer through agriculture lands (figure 9b) (ANOR 2003; Jalali 2009; Ako et al. 2014). The high standard deviation of nitrate in study area justified anthropogenic input in groundwater (table 1). The source of $\mathrm{Cl}^{-}$, $\mathrm{NO}_{3}^{-}$and $\mathrm{Na}^{+}$ions in groundwater are mostly agriculture fertilizers, animal waste and industrial and municipal sewage indicates the influence of human activities on water chemistry (Jalali 2009). 

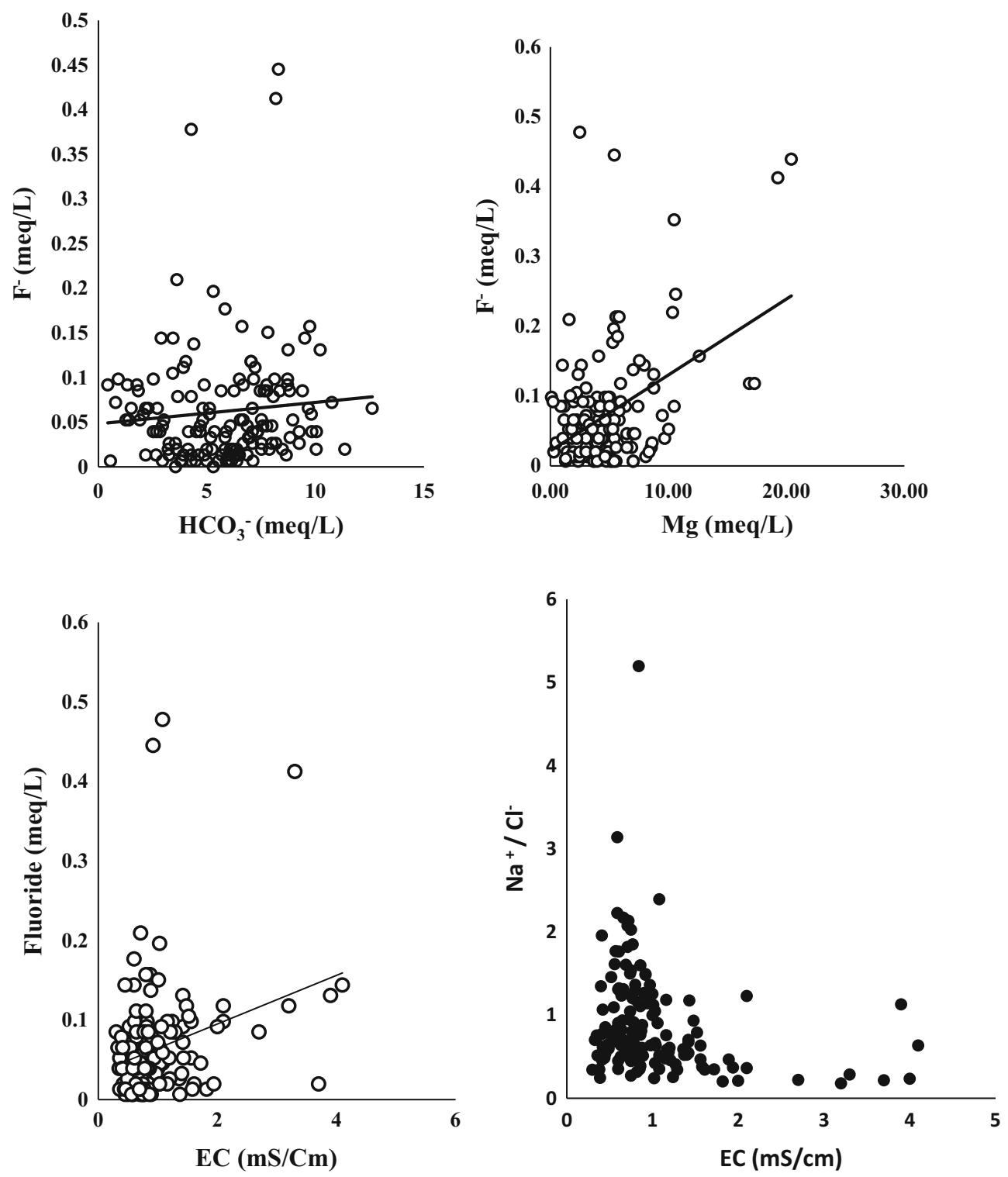

Figure 8. Graphical evaluation of fluoride enrichment in groundwater.

The geogenic source of nitrate in groundwater is controlled by nitrogen cycle in which $\mathrm{NH}_{4}^{+}$is converted to nitrate by the microbial activities (equations 8 and 9 ).

$$
\begin{aligned}
& 2 \mathrm{NH}_{4}^{+}+3 \mathrm{O}_{2} 2 \mathrm{~N} \longrightarrow \\
& \mathrm{O}_{2}^{-}+2 \mathrm{H}_{2} \mathrm{O} \text { (Nitrosomonas, Comammox), } \\
& 2 \mathrm{NO}_{2}^{-}+\mathrm{O}_{2} 2 \mathrm{~N} \longrightarrow \\
& \mathrm{O}_{3}^{-} \text {(Nitrobacter, Nitrospria, Comammox). }
\end{aligned}
$$

The contribution of $\mathrm{NO}_{3}^{-}$in groundwater by the geogenic source is very less $(<1.5 \mathrm{mg} / \mathrm{L})$
(Chen et al. 2016). The major contributions of nitrate in groundwater are anthropogenic activities like use of nitrogen-rich fertilizers in agriculture activities, municipal sewage and industrial effluent from fertilizer industry (NFL in this case study), other industries (WHO 2011; CGWB 2013). The dynamics of $\mathrm{NO}_{3}^{-}$contamination in groundwater is mainly influenced by soil characteristics, rainfalls, types of agriculture activities, availability of microorganisms, $\mathrm{pH}$ of soil and environmental condition (oxidizing or reducing) (Sajil Kumar 2017). The study area soils are ideal for the growth of leguminous plants and commercial agriculture activities are performed for leguminous plants like Glycine max (soyabean), 

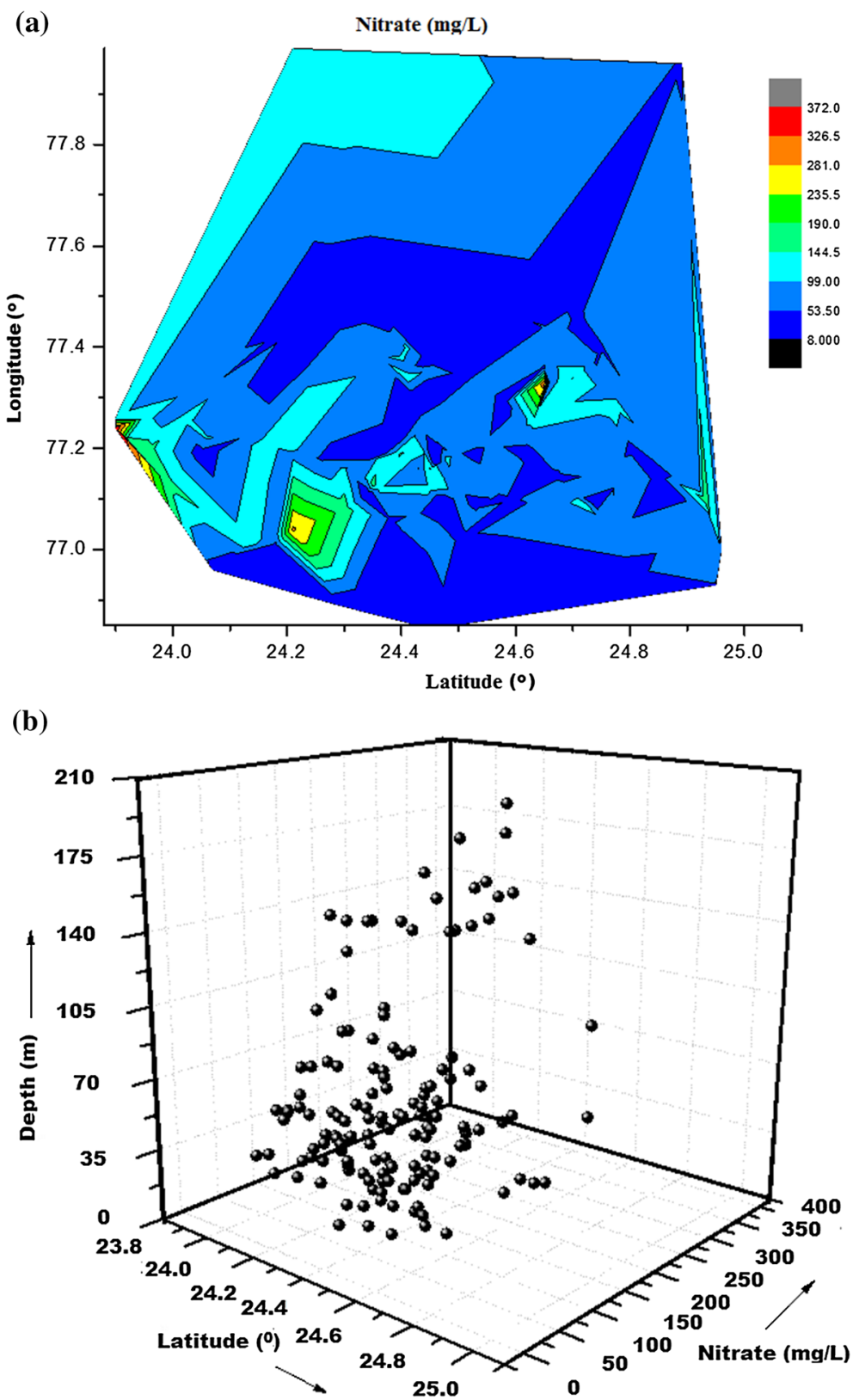

Figure 9. (a) Spatial distribution of nitrate in groundwater in the study area. (b) Distribution of nitrate in groundwater with depth below subsurface.

Chick pea (gram), Arachis hypogaea (groundnut), Vigna radiata (moong), and Cajanus cajan (arhar) in the study area. May be other possibilities for higher concentration of nitrate in soils and further leaching of nitrate causes contamination in the groundwater. The other intensive cropping in the study areas are Saccharumofficinarum (sugarcane), Triticum (wheat), Brassica oleracea (cauliflower), and Brassica oleracea var. capitate (cabbage). Ideally, these crops need excess quantity of fertilizer during farming, which may be one of the other reasons for the enrichment of soil by fertilizer and further contamination of ground water by leaching (Spalding and Exner 1993; Bohlke 2002; Jalali 2009). The most common fertilizer used in agriculture activities are urea $\left(\mathrm{NH}_{2} \mathrm{CONH}_{2}\right)$, Diammonium Phosphate (DAP) $\left[\left(\mathrm{NH}_{4}\right)_{2} \mathrm{HPO}_{4}\right], \mathrm{NP} / \mathrm{NPK}$ complex, single super phosphate (SSP). All these are rich in nitrogen and can be converted to $\mathrm{NO}_{3}^{-}$by nitrification (equations 8 and 9) (Chen et al. 2016)

$$
\left(\mathrm{NH}_{4}\right)_{2} \mathrm{HPO}_{4}(\mathrm{~s}) \longrightarrow \mathrm{NH}_{3}(\mathrm{~g})+\mathrm{NH}_{4} \mathrm{H}_{2} \mathrm{PO}_{4}(\mathrm{~s})
$$



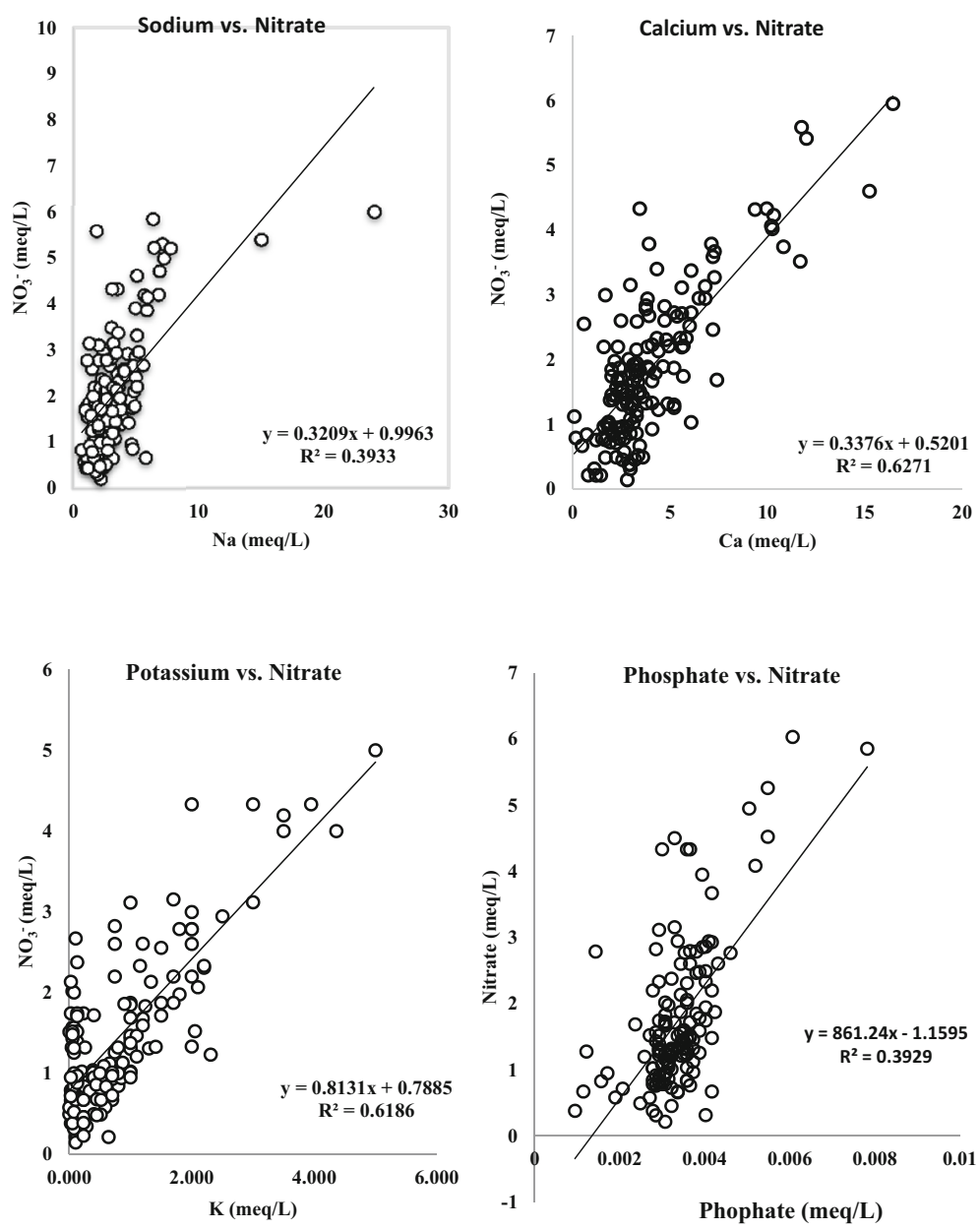

Figure 10. Graphical evaluation of contamination of groundwater by leaching of nitrate.

The bivariate plot of $\mathrm{Na}^{+}$vs. $\mathrm{NO}_{3}^{-}$and $\mathrm{Ca}^{2+}$ vs. $\mathrm{NO}_{3}^{-}$shows moderate and good correlation, indicates anthropogenic input of $\mathrm{NO}_{3}^{-}$in groundwater through leaching from agriculture lands in various proportions (figure 10). The bivariate plot between $\mathrm{K}^{+}$vs. $\mathrm{NO}_{3}^{-}$shows good correlation indicating the contribution of $\mathrm{NO}_{3}^{-}$by anthropogenic source (figure 10). While the bivariate plot between $\mathrm{PO}_{4}^{3-}$ vs. $\mathrm{NO}_{3}^{-}$shows both are contributed by similar source like NPK fertilizer (Jalali 2009) (figure 10). The various studies reported that the intake of nitrogen varies from species to species of various plants and soil characteristics, $\mathrm{pH}$, moisture in soil, etc. The intake of nitrogen in plants is $<50 \%$ and remaining $(>50 \%)$ left in the soil and further leached in groundwater along with irrigated water or rainwater. The high concentration of $\mathrm{NO}_{3}^{-}$causes pollution in groundwater and nutrients enrichment in surface water and further eutrophication in surface water (Srivastava and Ramanathan 2012).

\subsection{Trace metals ( $\mathrm{Hg}, \mathrm{Fe}, \mathrm{Cu}, \mathrm{Pb})$}

The trace metals $(\mathrm{Hg}, \mathrm{Fe}, \mathrm{Cu}, \mathrm{Pb})$ concentration was observed more than the permissible limit of BIS (2012) and WHO (2004, 2011) in few locations, may be due to some anthropogenic input (table 1). The spatial distribution indicates very low concentration of $\mathrm{Hg}$ in most of the area of the district (figure 11). The spatial distribution of $\mathrm{Fe}$ shows most of the groundwater is under the permissible limit, except few may be due to local input (figure 11). The spatial distribution of $\mathrm{Cu}$ indicates large area possess significant concentration (figure 11). It also indicates the possibility of the geogenic contribution of $\mathrm{Cu}$, which is available in significant proportions in the geology of the study area (Wadia 1981). The spatial distribution of lead indicates that most of the area shows low concentration than the permissible limit except for few samples. It may occur due to some anthropogenic input (figure 11). 

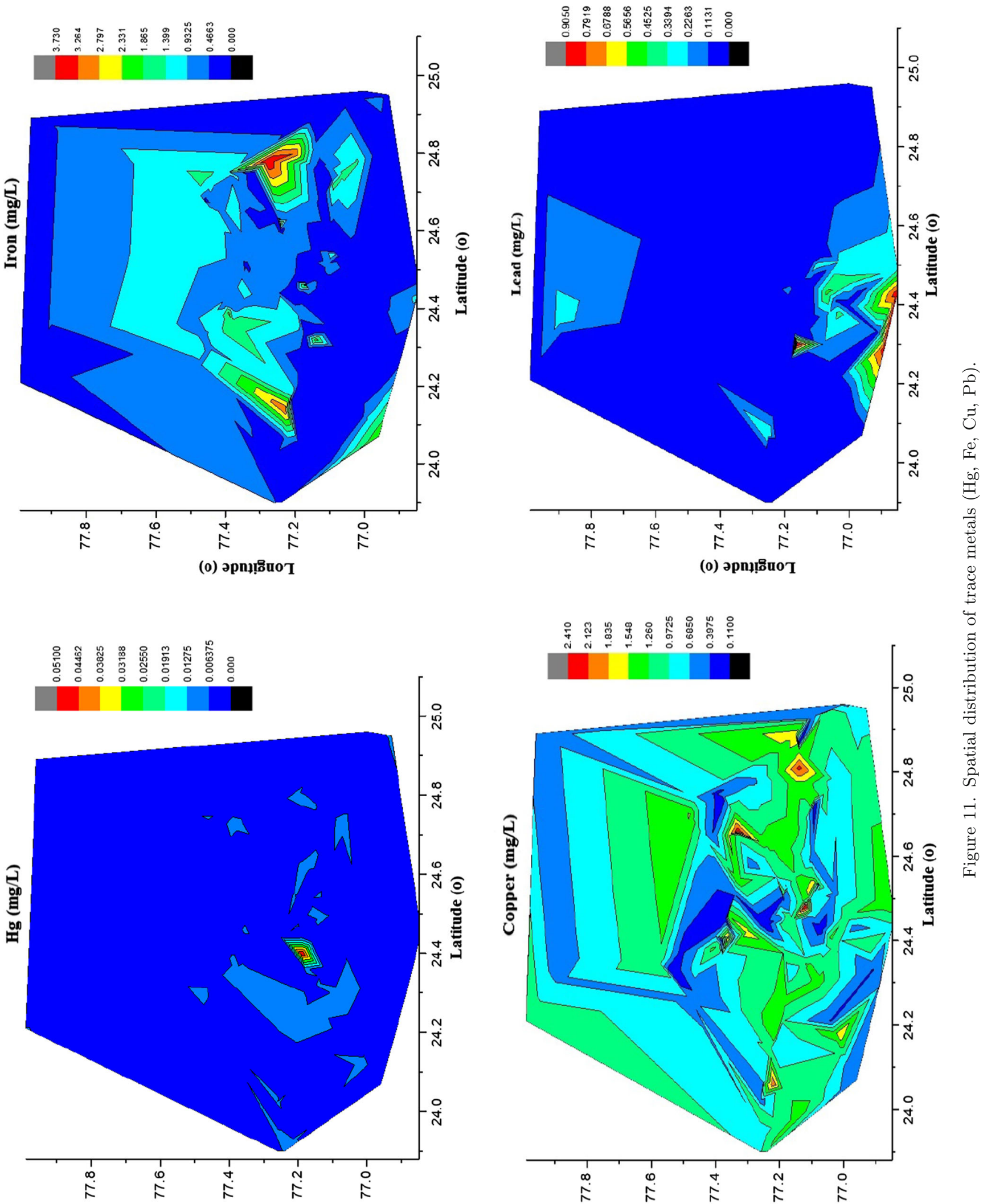

InUM!

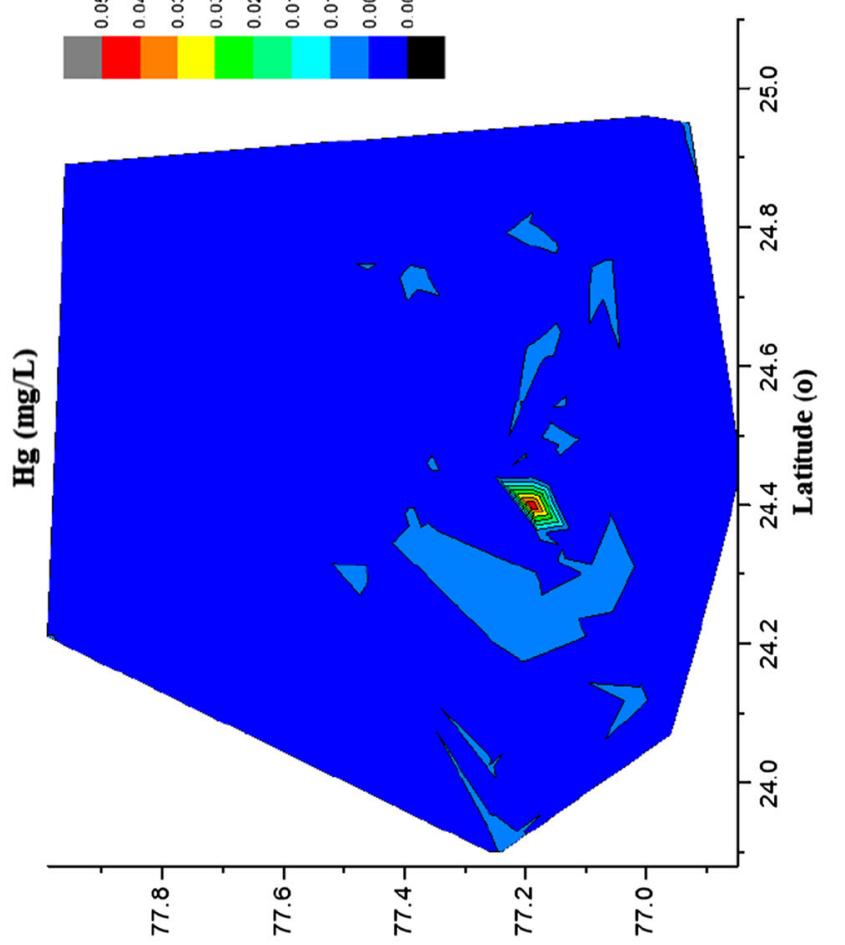

(o) วрn!ฺถิณоา

(o) วpn!̣oิuo T 


\section{Conclusions}

The statistical assessment of hydrogeochemical parameters of the groundwater samples shows good charge balance ranging from $\pm 5.0 \%$ error. The various location in the Guna district shows the higher value of $\mathrm{NO}_{3}^{-}, \mathrm{F}^{-}, \mathrm{Cl}^{-}, \mathrm{HCO}_{3}^{-}, \mathrm{PO}_{4}^{3-}$, $\mathrm{Mg}^{2+}, \mathrm{Ca}^{2+}, \mathrm{Na}^{+}, \mathrm{K}^{+}, \mathrm{EC}, \mathrm{TDS}, \mathrm{Fe}^{2+}$, and $\mathrm{Cu}^{2+}$ than the permissible limit given in BIS (2012) and WHO (2004, 2011). Piper and Chaddha diagram indicate $\sim 59.73 \%$ groundwater are the $\mathrm{Ca}-\mathrm{Mg}-\mathrm{HCO}_{3}$ water-type, $\sim 28.19 \%$ groundwater $\mathrm{Ca}-\mathrm{Mg}-\mathrm{SO}_{4}-\mathrm{Cl}$ water-types, $\sim 8.72 \%$ groundwater $\mathrm{Na}-\mathrm{K}-\mathrm{SO}_{4}-\mathrm{Cl}$ water-types and $3.36 \%$ groundwater $\mathrm{Na}-\mathrm{K}-\mathrm{HCO}_{3}$ water-types. This classification of hydrogeochemical facies indicates dissolution and mixing are primarily controlling groundwater chemistry in the study area. Water quality index (WQI) of study area indicate $\sim 22.81 \%$ groundwater are good-water, $\sim 71.14 \%$ groundwater poorwater, $\sim 5.37 \%$ groundwater very poor-water and $0.67 \%$ groundwater unsuitable for drinking purpose. Around $49.66 \%$ groundwater show low sodium hazard and moderate salinity hazard, $\sim 44.30 \%$ groundwater show low sodium hazard and medium salinity hazard, $\sim 3.36 \%$ groundwater show high salinity hazard and low sodium hazard; while $\sim 0.67 \%$ groundwater show various salinity and sodium hazard. Higher soil permeability observed in $\sim 91.56 \%$ groundwater, while $1.3 \%$ groundwater show lower permeability of the soil and higher drainage problems. Approximately $7.14 \%$ groundwater show medium permeability and medium drainage problems. Sodium adsorption ratio (SAR) indicates $\sim 97.99 \%$ groundwater are in excellent condition $(<10), \sim 1.34 \%$ good condition (10-18) and $0.67 \%$ unfair (18-26) for irrigation. Based on $\mathrm{Cl}^{-}$concentration $\sim 27.52 \%$ ground-water samples are very-fresh, $\sim 47.65 \%$ groundwater fresh, $\sim 13.42 \%$ groundwater freshbrackish, $\sim 10.74 \%$ brackish and $0.67 \%$ groundwater brackish salt. Almost all water samples susceptible to corrosive properties as per Ryzner classification due to high corrosive index $(>1)$.

Significant fluoride concentration is observed in almost all the blocks of the Guna district. The spatial distribution indicates the high concentration of fluoride in the Western Guna, which may be due to presence of fluoride-rich minerals in the geology. The various localities in the Guna district show higher concentration of fluoride than the permissible limit (1.5 mg/L) of BIS (2012) and WHO (2004, 2011). There is no major variation of fluoride concentration observed in depth indicating major contribution through geology of the study area. In general, fluoride concentration ranges from 0.50 to $8.46 \mathrm{mg} / \mathrm{L}$ in the Kumbhraj, 0.01 to $2.99 \mathrm{mg} / \mathrm{L}$ in the Raghogarh, 0.12 to $1.87 \mathrm{mg} / \mathrm{L}$ in the Aron, 0.12 to $1.87 \mathrm{mg} / \mathrm{L}$ in the Guna, 0.12 to $2.74 \mathrm{mg} / \mathrm{L}$ in the Bamori and 0.25 to $9.08 \mathrm{mg} / \mathrm{L}$ in the Chachoda block.

A large area of the Guna district is used for intensive farming and these agricultural activities need significant quantity of water. Most of the bore wells used for irrigation are located on agriculture land, which further increases the probability of leaching of fertilizer from agriculture land. It is also justified by the spatial distribution of nitrate in groundwater of the study area. The spatial distribution shows the high concentration of nitrate in agriculture dominated area. Highest concentration of nitrate observed near fertilizer industry (NFL) indicates contamination of nitrate through point source also. The hydrogeochemical behavior of $\mathrm{NO}_{3}^{-}$in groundwater is strongly influenced by the presence of plants, animal waste and anthropogenic input (fertilizer, industrial effluent, and animal excreta). The statistical assessment of $\mathrm{NO}_{3}^{-}$concentration in groundwater of the study area indicates $\sim 33.33 \%$ groundwater samples of Kumbharaj, $\sim 79.66 \%$ of Raghogarh, $\sim 59.09 \%$ of Aron, $\sim 76.47 \%$ of Guna, $\sim 79.31 \%$ of Bamoriand $\sim 70.0 \%$ of Chachoda block shows $\mathrm{NO}_{3}^{-}$concentration more than the permissible limit of drinking water as recommended by WHO $(2004,2011)$ and BIS (2012). These indicate that a large proportion ( $\sim 69.8 \%$ ) of groundwater need to be treated before utilization for drinking purpose. Nitrate contamination in groundwater can be reduced by reducing the consumption of fertilizer, which is responsible for leaching of $\mathrm{NO}_{3}^{-}$in groundwater. Fluoride enrichment can be also reduced by reducing the consumption of groundwater. Reducing stress over groundwater consumption also reduces dissolution of fluoride-rich minerals, which are responsible for fluoride enrichment in groundwater.

\section{Acknowledgements}

The first author would like to thank Madhya Pradesh Council of Science and Technology (MPCOST) for sponsoring the research project (Research Grant No. R \& D Project (Physical and Engineering Science)/1203/CST/R\&D/2016) for hydrogeochemical assessment of the groundwater 
quality of Guna district located in Madhya Pradesh. India. Authors also thank Central Ground Water Board (CGWB), Survey of India (SOI), Central Pollution Control Board and authorities of Jaypee University of Engineering and Technology (JUET) for providing valuable assistance during research activities. Authors also thank Mr. Adarsh Gupta for his help during sampling and analysis of groundwater samples.

\section{References}

Agarwal R 2012 Nitrate contamination in groundwater samples of Gangapur city town (Sawai Madhopur district) Rajasthan; J. Chem. Biol. Phys. Sci. 2(1) 511-513.

Aiuppa A, Bellomo S, Brusca L D, Alessandro W and Federico W C 2003 Natural and anthropogenic factors affecting groundwater quality of an active volcano (Mt. Etna Italy); Appl. Geochem. 18 863-882.

Akao A A, Jun S, Takahiro H, Kimpei I, Nkeng G E, Fantong W Y, Eyong G E T and Ntankouo N R 2011 Evaluation of groundwater quality and its suitability for drinking, domestic and agriculture use in the Banan Plain (Mbanga, Njombe, Penja) of the Cameroon Volcanic; Environ. Geochem. Hlth. 33 559-575.

Ako A A, Eyong G E T, Shimada J, Koike K, Hosono T, Ichiyanagi K, Richard A, Tandia B K, Nkeng G E and Roger N N 2014 Nitrate contamination of groundwater in two areas of the Cameroon Volcanic Line (Banan Plain and Mount Cameroon area); Appl. Water Sci. 4(2) 99113, https://doi.org/10.1007/s13201-013-0134-x.

ANOR 2003 Cameroon drinking water quality norms (NC 207:2003-02); Agence Nationale des Norms et Qualite, Younde.

Apambire W B, Boyle Dr and Michel F A 1997 Geochemistry, genesis and health implication of floriferous groundwater in the upper regions of Ghana; Environ. Geol. 33 13-24.

APHA (American Public Health Association) 1995 Standard methods for the examination of water and waste water; 19th edn, American Public Health Association, Washington DC.

Appelo C A J and Postma D 2005 Geochemistry, Groundwater and Pollution; 2nd edn, AA Balkema Publishers, Amsterdam, Netherlands, 634p.

Assaf H and Saadeh M 2009 Geostatistical assessment of groundwater nitrate contamination with reflection on DRASTIC vulnerability assessment: The case of Upper Litani Basin, Lebanon; Water Resour. Manag. 23 775796.

Balasubramanian A, Sharma K K and Sastri J C V 1985 Geo-electrical and hydrogeochemical evaluation of coastal aquifer of Tambraarni basin, Tamilnadu; Geophys. Resour. Bull. 23 203-209.

Batabyal A K and Chakraborty S 2015 Hydrogeochemistry and water quality index in the assessment of groundwater quality for drinking uses; Water Environ. Res. 87(7) $607-617$
Berner E K and Berner R A 1987 The global water cycle, geochemistry, and environment; Prentice Hall, Englewood Cliffs, New Jersey, USA.

BIS 2012 Indian Standard specifications for drinking water IS:10500, Bureau of Indian Standards, New Delhi.

Bohlke J K 2002 Groundwater recharge and agriculture contamination; J. Hydrol. 10 153-179.

Cederstrom D J 1946 Genesis of groundwater in the coastal plain of Virginia; Environ. Geol. 41 218-245.

Census of Government of India 2011 Office of Registrar General and Census Commissioner, Govt. of India.

CGWB (Central Groundwater Board, Bhopal) 2013 Annual report published for groundwater of Guna district, India, http://www.cgwb.gov.in/District_Profile/MP/guna.pdf.

Chadha D K 1999 A proposed new diagram for geochemical classification of natural waters and interpretation of chemical data; Hydrogeol. J. 7 431-439.

Chaïrat C, Schott J, Oelkers E H, Lartigue J E and Harouiya N 2007 Kinetics and mechanism of natural fluorapatite dissolution at $25^{\circ} \mathrm{C}$ and $\mathrm{pH}$ from 3 to 12 ; Geochim. Cosmochim. Acta 71 5901-5912.

Chen J, Wu H, Qian H and Gao Y 2016 Assessing nitrate and fluoride contaminants in drinking water and their health risk of rural residents living in a semiarid region of northwest China; Exp. Hlth., https://doi.org/10.1007/ s12403-016-0231-9.

Doneen L D 1964 Water quality for agriculture; Department of Irrigation, University of California, Davis, USA.

Drever J I 1988 The geochemistry of natural water; PrenticeHall Inc., New York.

Eaton F M 1950 Significance of carbonates in irrigation waters; Soil Sci. 69 123-133.

Edmond J M, Palwar M R, Measure C F, Grant B and Stallard R F 1995 The fluvial geochemistry and denudation rate of the Guyana Shield in Venezuela; Geochim. Cosmochim. Acta 59 3301-3323.

Freeze R A and Cherry J A 1979 Groundwater; PrenticeHall, New Jersey, USA, 603p.

Guler C, Thyne G D, Mc Cra J E and Turner A K 2002 Evaluation of graphical and multivariate statistical methods for classification of water chemistry data; Hydrogeol. J. 10 455-474.

Guo Q, Wand Y, Ma T and Ma R 2007 Geochemical processes controlling the elevated fluoride concentrations in groundwater of the Taiyuan basin, Northern China; J. Geochem. Expl. 93 1-12.

Handa B K 1975 Geochemistry and genesis of fluoridecontaining groundwater of India; Groundwater 13 275281.

Hem J D 1991 Study and interpretation of the chemical characteristics of natural water; US Geological Survey Water-Supply Paper 2254, Scientific Publ.

Huh Y, Tsoi M, Zaitiser A and Edward J N 1998 The fluvial geochemistry of the river of eastern Siberia. Tributaries of Lena River draining the sedimentation platform of the Siberia Craton; Geochim. Cosmochim. Acta $621657-$ 1676 .

Indian Meteorological Department 2016 Annual report for Madhya Pradesh, New Delhi, India.

Jalali M 2009 Geochemistry characterization of groundwater in an agriculture area of Razan, Hamadan, Iran; Environ. Geol. 56 1479-1488. 
Karnath K R 1991 Impact of human activities on the hydrogeological environment; J. Geol. Soc. India 38 195206.

Kebede S, Travi Y, Alemayehu T and Ayenew T 2005 Groundwater recharge, circulation and geochemical evaluation in the source region of the Blue Nile River, Ethopia; Appl. Geochem. 20(3) 1658-1676.

Kundu M C, Mandal B and Sarkar D 2008 Assessment of the potential hazardous nitrate contamination in surface and in groundwater in the heavily fertilized and intensively cultivated district of India; Environ. Monit. Assess. 146 183-189.

Kyoung-Ho K, Seong Track Y, Byoung Young C, GiTak C, Yongsung J, Kangjoo K and Hyoung Soo K 2009 Hydrochemical and multivariate statistical interpretations of spatial controls of nitrate concentration in a shallow alluvial aquifer around oxbow lakes (Osong area, Central Korea); J. Contam. Hydrol. 107 114127.

Lawrence F W and Upchurch S B 1982 Identification of recharge areas using geochemical factor analysis; Ground Water 20 680-687.

Lawrence J F and Balasubramanian A 1994 Groundwater condition and disposition of salt-fresh water interaction in the Rameswaram island, Tamilnadu; Regional workshop on environment aspect of groundwater development, October 17-19, Kurukshetra, India.

MP Government 2012 Madhya Pradesh Agriculture Contingency Plan: District Guna; http://www.crida. in/CP-2012/statewiseplans/madhya\%20pradesh/MP6-G una-26.6.2012.pdf.

Madhnure P, Sirsikar D Y, Tiwari A N, Ranjan B and Malpe D B 2007 Occurrence of fluoride in the groundwater of Pandharkawada area, Yavatmal district, Maharastra, India; Curr. Sci. 92 675-679.

Marghade D, Malpe D B and Zade A B 2011 Major ion chemistry of shallow groundwater of fast-growing city of central India; Environ. Monit. Assess., https://doi.org/ 10.1007/s10661-011-2126-3.

Moore K B, Ekwurzel B and Esser B K 2006 Sources of groundwater nitrate revealed using residence time and isotope methods; Appl. Geochem. 21 1016-1029.

Ngounou Ngatch B and Djoret D 2010 Nitrate pollution in groundwater in two selected areas from Cameroon and Chad in the Lake Chad basins; Water Policy 12(5) 722 733.

Nordstrom D K and Jenne E A 1977 Fluorite solubility equilibria in selected geothermal waters; Geochim. Cosmochim. Acta 41 175-188.

Piper A M 1944 A graphic procedure in geochemical interpretation of water analysis; Trans. Am. Geophys. Union 25(6) 914-928.

Ranjan R, Srivastava S K and Ramanathan A L 2017 An assessment of hydrogeochemistry of two wetlands located in Bihar State in the subtropical climatic zone of India; Environ. Earth Sci. 76(16) 1-17, https://doi. org/10.1007/s12665-016-6330-x.

Ray C and Schock S C 1996 Comparability of large-scale studies of agriculture chemical contamination of rural private well; Ground Water Monit. Remed. 16(2) 92102.
Reddy A G S 2013 Geochemical evaluation of nitrate and fluoride contamination in varied hydrogeological environs of Prakasam district, southern India; Environ. Earth Sci. $714473-4495$.

Richard L A 1954 Diagnosis and improvement of saline and alkali soils; Agriculture handbook 60, US Department of Agriculture, Washington DC.

Ryzner J W 1944 A new index for determining the amount of $\mathrm{CaCO}_{3}$ formed by water; J. Am. Water Work Assoc. 36(4) 472.

Sajil Kumar P J 2017 Geostatistical modeling of fluoride enrichment and nitrate contamination in groundwater of lower Bhavani Basin in Tamil Nadu, India; Model. Earth Syst. Environ. 3(1) 1-10, https://doi.org/10.1007/ s40808-016-0260-1.

Sajil Kumar P J, Jegathambal P and James E J 2014 Factors influencing the high fluoride concentration in groundwater of Vellore district, South India; Environ. Earth Sci. 72(7) 2437-2446.

Schoeller H 1955 Geochimie des eauxsouterraines application auxeaux de gisements de petrole; Revue Inst. Petrole et Ann des combustibles liquids 10(181-213) 219246.

Schoeller H 1977 Geochemistry of groundwater; An international guide for research and practice. UNESCO, Chap. 15, $1-18$.

Spalding R F and Exner M E 1993 Occurrence of nitrate in groundwater - a review; J. Environ. Qual. 22(3) 392-402.

Srivastava S K and Ramanathan A L 2008 Geochemical assessment of groundwater quality in the vicinity of Bhalswa landfill, Delhi, India, using graphical and multivariate statistical methods; Environ. Geol. 53(7) 1509-1528, https://doi.org/10.1007/s00254-007-0762-2.

Srivastava S K and Ramanathan A L 2012 Groundwater in the vicinity of the landfill: Application of graphical and multivariate statistical method for hydrogeochemical characterization of groundwater; Lambert Academic Publishing, Germany, 380p.

Stumm W and Morgan J J 1996 Aquatic Chemistry: An introduction emphasizing chemical equilibria in natural waters; Wiley Inter-Science, New York.

Stuyfzand P J 1989 Nonpoint source of trace element in potable groundwater in the Netherland; Proceedings of 18th TWSA water workings, testing, and research institute, KIWA.

Subba Rao N, Dinakar A, Surya Rao P, Rao P N, Madhnure P, Prasad K M and Sudarshan G 2016 Geochemical processes controlling fluoride bearing groundwater in the granite aquifer of a semi-arid region; J. Geol. Soc. India 88 350-356.

Suthar S, Preeti B, Sushma S, Pravin K M, Arvind K N and Nagraj S P 2009 Nitrate contamination in groundwater of some rural areas of Rajasthan, India; J. Hazard. Mater. 171(1-3) 189-199, https://doi.org/10.1016/ j.jhazmat.2009.05.111.

UNICEF 1999 States of the art report on the extent of fluoride in drinking water and the resulting endemicity in India; Report by fluorosis and rural development foundation for UNICEF, New Delhi, India. 
USSL 1954 Diagnosis and improvement of saline and alkali soils; USDA Handbook 60147.

Vengosh A and Rosenthal E 1994 Saline Groundwater in Israel: It's bearing on the water crisis in the country; J. Hydrol. 156 389-430.

Wadia D N 1981 Geology of India; Tata McGraw-Hill, New Delhi, 508p.

WHO 2004 Guidelines for drinking-water quality; Health criteria and other supporting information, 2nd edn, World Health Organization, Geneva.

Corresponding editor: N V CHALAPATHI RAO
WHO 2011 Guidelines for drinking-water quality; 4th edn, World Health Organization, Geneva.

Wilcox L V 1955 Classification and uses of irrigation waters; United States Department of Agriculture Washington DC 969 1-19, https://www.ars.usda.gov/arsuserfiles/ 20360500/pdf_pubs/P0192.pdf.

Wodeyar B K and Sreenivasan G 1996 Occurrence of fluoride in the groundwater and its impact in Peddavankahall Basi, Bellary District, Karnataka, India a preliminary study; Curr. Sci. 70 71-74. 